\title{
Do New-Generation Recycled Phosphorus Fertilizers Increase the Content of Potentially Toxic Elements in Soil and Plants?
}

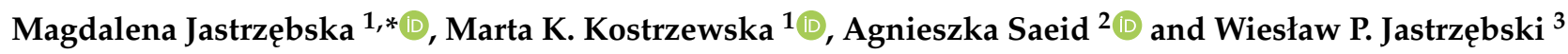 \\ 1 Department of Agroecosystems and Horticulture, Faculty of Agriculture and Forestry, University of Warmia \\ and Mazury in Olsztyn, Plac Łódzki 3, 10-718 Olsztyn, Poland; marta.kostrzewska@uwm.edu.pl \\ 2 Department of Engineering and Technology of Chemical Processes, Faculty of Chemistry, Wroclaw University \\ of Science and Technology, Wyspiańskiego 42, 50-376 Wrocław, Poland; agnieszka.saeid@pwr.edu.pl \\ 3 Department of Botany and Nature Protection, Faculty of Biology and Biotechnology, University of Warmia \\ and Mazury in Olsztyn, Plac Łódzki 1, 10-727 Olsztyn, Poland; w.jastrzebski@uwm.edu.pl \\ * Correspondence: jama@uwm.edu.pl
}

Citation: Jastrzębska, M.;

Kostrzewska, M.K.; Saeid, A.;

Jastrzębski, W.P. Do New-Generation

Recycled Phosphorus Fertilizers

Increase the Content of Potentially

Toxic Elements in Soil and Plants?

Minerals 2021, 11, 999. https://

doi.org/10.3390/min11090999

Academic Editor: Maja Radziemska

Received: 19 August 2021

Accepted: 10 September 2021

Published: 13 September 2021

Publisher's Note: MDPI stays neutral with regard to jurisdictional claims in published maps and institutional affiliations.

Copyright: (C) 2021 by the authors. Licensee MDPI, Basel, Switzerland. This article is an open access article distributed under the terms and conditions of the Creative Commons Attribution (CC BY) license (https:// creativecommons.org/licenses/by/ $4.0 /)$.

\begin{abstract}
Phosphorus (P)-rich secondary raw materials can provide a valuable base for modern mineral fertilizers, provided that the new formulations do not load the soil-plant system with potentially toxic elements. Fertilizers from sewage sludge ash (SSA) and/or animal bones, activated by phosphorus-solubilizing bacteria (Bacillus megaterium or Acidithiobacillus ferrooxidans), were tested in field experiments in north-eastern Poland. The reference provided treatments with superphosphate and treatment without phosphorus fertilization. In one experiment, all P-fertilizers were applied at a P dose of $21 \mathrm{~kg} \cdot \mathrm{ha}^{-1}$, and in the other three experiments, three P doses were adopted: 17.6, 26.4, and $35.2 \mathrm{~kg} \cdot \mathrm{ha}^{-1}$. The effect of recycled fertilizers on the content of arsenic (As), chromium (Cr), nickel $(\mathrm{Ni})$, copper $(\mathrm{Cu})$, and zinc $(\mathrm{Zn})$ in the soil, in wheat grain and straw (test plant), weeds, and post-harvest residues was investigated. The application of recycled fertilizers in $\mathrm{P}$ amounts up to $35.2 \mathrm{~kg} \cdot \mathrm{ha}^{-1}$ did not change the $\mathrm{As}, \mathrm{Cr}, \mathrm{Ni}, \mathrm{Cu}$, or $\mathrm{Zn}$ contents in the soil and plant biomass. The contents of these elements in soil were below the permissible levels for arable land in Poland. Their concentrations in wheat grain and straw did not exceed the permissible or suggested limits for plant material to be used for food and feed, while in the weed and post-harvest residue biomass, they usually fell within the biological plant variability ranges.
\end{abstract}

Keywords: phosphorus recovery; secondary raw materials; waste management; microbial solubilization; biofertilizers; heavy metals

\section{Introduction}

Although agriculture is the major food supplier for the growing world population, it is also one of the economic sectors with the largest environmental impact [1]. Among others, different studies have revealed a higher trend of accumulation of toxicants in different spheres of the environment, posing harmful effects to aerial, aquatic, and terrestrial health due to the injudicious applications of agrochemicals [2]. Potentially toxic elements (PTE), including heavy metals and metalloids, are at the top of the list of environmental toxicants from agricultural activities [3].

PTE are known to be naturally occurring elements [4], but they become dangerous when their concentration in different environmental compartments exceeds the prescribed levels [3,5]. Certain PTE, such as $\mathrm{Cu}, \mathrm{Fe}, \mathrm{Ni}, \mathrm{Zn}$, and even $\mathrm{Cr}(\mathrm{III})$, are essential elements to organisms [6]; however, they cause toxic effects when present in excessive quantities [7]. Their functions and potential toxicity have been comprehensively discussed in the literature [8-10]. Several PTE, e.g., As, $\mathrm{Pb}, \mathrm{Cd}$, and $\mathrm{Hg}$, are non-essential to metabolic and other biological functions [11,12]. These are hazardous to organisms even at low levels [7] and harmful in various respects [13]. Persistent toxicity and bioaccumulation in food chains make PTE one of the most problematic types of pollutants [14]. 
Among the agricultural PTE sources, fertilizers are the most common, and of these, phosphorus (P) fertilizers have been identified as the main source of PTE contamination of soil [9], especially if applied for a long time [15]. PTE are usually found in P-fertilizers because of the high amounts of these contaminants contained in raw materials, i.e., phosphate rocks (PR) [16-18]. PR contamination with PTE is natural, yet the level of these elements is variable, depending on the deposit source $[19,20]$. For example, the Cd concentration in PR in the world tends to be higher in North Africa (with the content up to $60 \mathrm{mg} \cdot \mathrm{kg}^{-1}$ ), $\mathrm{Pb}$ is higher in PR of Brazil $\left(44.5 \mathrm{mg} \cdot \mathrm{kg}^{-1}\right)$, and the highest Zn concentration occurs in the PR of Tunis (515 $\mathrm{mg} \cdot \mathrm{kg}^{-1}$ ) [20].

Mined PR are either applied directly to soils or manufactured to produce water-soluble P-fertilizers [16], which are, therefore, accompanied by PTE [21]. PTE content is not included in the commercial fertilizer label, but according to Nziguheba and Smolders [22], for example, the average PTE concentrations in phosphate fertilizers sold on the European market were: $7.6 \mathrm{mg} \cdot \mathrm{kg}^{-1} \mathrm{As}, 7.4 \mathrm{mg} \cdot \mathrm{kg}^{-1} \mathrm{Cd}, 89.5 \mathrm{mg} \cdot \mathrm{kg}^{-1} \mathrm{Cr}, 14.8 \mathrm{mg} \cdot \mathrm{kg}^{-1} \mathrm{Ni}$, $2.9 \mathrm{mg} \cdot \mathrm{kg}^{-1} \mathrm{~Pb}$, and $166 \mathrm{mg} \cdot \mathrm{kg}^{-1} \mathrm{Zn}$. Many countries have regulations regarding limits on the maximum concentrations of PTE allowed in P-fertilizers [23,24]. Since Cd is the most studied toxic metal due to its high mobility and transfer rate from soil to crops [21], most of the fertilizer regulations relate $\mathrm{Cd}$ limits to $\mathrm{P}$ concentrations [25]. By 2036, the European Parliament (EP) is planning to tighten Cd limits to $20 \mathrm{mg}$ per $1 \mathrm{~kg} \mathrm{P}_{2} \mathrm{O}_{5}$ [26].

Phosphorus $(\mathrm{P})$ is one of the essential elements needed for global food security. However, phosphate rocks (PR)—a primary P source—are finite and non-renewable [27]. Their uneven distribution over the globe and location mainly in geopolitically sensitive regions aggravate the problem and make many countries, including EU countries, dependent on raw material imports $[27,28]$. Moreover, the phosphate rock life cycle is, currently, predominantly linear, and there are approximately $80 \% \mathrm{P}$ losses along the value chain "from mine to fork" [28,29]. The lost $P$ ends up in waste, plant-unavailable P reservoirs in soils (legacy P), or in aquatic ecosystems [28,30,31].

Solutions to these problems can be found in closing the P loop, i.e., in recovering and recycling $\mathrm{P}$ as well as using it more efficiently [27,32]. Different types of bio-waste (e.g., municipal, food, agricultural) were valorized [33] and, among others, sewage sludge ashes (SSA) and animal bones have been identified as good raw materials for P-fertilizers [34]. Apart from being rich in $\mathrm{P}$, these wastes can also serve as carriers of other macro- and micronutrients [35]. However, there are some barriers that must be overcome in order to use these resources effectively and safely for people and the environment [36].

Unlike sewage sludge, SSA is free of organic pollutants, but without further processing, it is poorly plant-available [37-40] and may contain elevated amounts of PTE, which restricts its direct use for agricultural purposes [41,42]. Thus, post-treatment is usually necessary in order to increase plant availability and to remove PTE [36]. There are several modern technologies for P recovery from SSA, such as thermo-chemical, acidic wet-chemical leaching, thermo-electric, and acidic wet-chemical extraction, which remove PTE from SSA or reduce their content to an acceptable level [43]. Finally, the PTE content in SSA varies widely depending on the sludge origins and treatment options [43]. For example, the thermochemically treated SSA from various plants of municipal sewage sludge combustion in Poland, tested by Smol et al. [43], contained $4.8-22.7 \mathrm{mg} \cdot \mathrm{kg}^{-1}$ As, 0.9-2.8 $\mathrm{mg} \cdot \mathrm{kg}^{-1} \mathrm{Cd}, 99.0-547.4 \mathrm{mg} \cdot \mathrm{kg}^{-1} \mathrm{Cr}, 32.8-49.6 \mathrm{mg} \cdot \mathrm{kg}^{-1} \mathrm{Cu},<0.05 \mathrm{mg} \cdot \mathrm{kg}^{-1} \mathrm{Hg}$, $48.9-491.4 \mathrm{mg} \cdot \mathrm{kg}^{-1} \mathrm{Ni}, 10.2-73.1 \mathrm{mg} \cdot \mathrm{kg}^{-1} \mathrm{~Pb}$, and $1072.8-4459.9 \mathrm{mg} \cdot \mathrm{kg}^{-1} \mathrm{Zn}$, and met the Polish norms for trace elements covered by the legislation. The production of fertilizers in the P extraction processes from SSA is recommended [43], followed by a holistic evaluation of their effects in field conditions [44].

Bone raw material is not thought to be hazardous with PTE $[35,45]$. However, the primary P mineral in bones, calcium-deficient hydroxy-apatite, is much less soluble than conventional P fertilizers, although it is more soluble than PR [46,47]. Soil amendment using bones has been known since biblical times [48]. In modern times, bone meal (BM) and meat and bone meal (MBM) have been approved (with some limitations) for use 
in agriculture as soil improvers [49] and have been reported from different countries to be effective in yield enhancement [50-54]. Recently, new technologies have emerged to produce bone-based fertilizers through thermal and/or chemical transformations [55-57].

An innovative alternative technology of recycled $P$ fertilizer production is the inclusion of phosphorus-solubilizing microbes (PSM) into waste-based preparations [34]. Due to the release of weak organic (e.g., by Bacillus megaterium, bacteria naturally occurring in soil) or inorganic acids (e.g., by Acidithiobacillus ferrooxidans, bacteria active in strongly acidic ( $\mathrm{pH}$ 2.5) environments), PSM increase the solubility of the phosphorus raw material [58]. Several recycled fertilizers have been developed using this technology [34] and evaluated for their agronomic utility in field experiments against traditional P-fertilizers [59]. In addition to satisfactory yields, the new formulations are expected to provide safety for field crop consumers and for the environment. This safety will not be guaranteed if the soilplant system is loaded with PTE through the recycled fertilizer application. The issue of $\mathrm{Cd}$ and $\mathrm{Pb}$ presence in soil and plant biomass after the application of recycled PSM-containing fertilizers has been addressed previously [60]. This paper focuses on the effect of fertilizers from SSA and/or animal bones, activated by PSM (Bacillus megaterium or Acidithiobacillus ferrooxidans) on the content of $\mathrm{As}, \mathrm{Cr}, \mathrm{Ni}, \mathrm{Cu}$, and $\mathrm{Zn}$ in the soil, in wheat grain and straw (test plant), wheat associated weeds, and post-harvest residues.

\section{Materials and Methods}

\subsection{Fertilizers}

In field experiments, six recycled phosphorus fertilizers were tested against a commercial fertilizer superphosphate (SP). The new products, in the form of suspension or granular, were produced from sewage sludge ash (ash from the incineration of sewage sludge biomass from wastewater treatment; SSA) and/or animal (poultry) bones. Five of them were activated by PSM of the Bacillus megaterium or Acidithiobacillus ferrooxidans strains (Table 1). The recycled fertilizers were manufactured at the Institute of New Chemical Syntheses in Puławy (Poland), following a concept elaborated at the Wrocław University of Science and Technology (Poland). Raw materials originated from the following sources: SSA from the municipal wastewater treatment plant 'Eyna' in Olsztyn and bones from households or from the Firma Handlowo-Produkcyjna 'Podolski' (registered office in Lutomek, Wielkopolskie Voivodeship, Poland). Bacterial strains were acquired from the Polish Collection of Microorganisms at the Institute of Immunology and Experimental Therapy of the Polish Academy of Sciences in Wrocław (Poland). Table 2 shows the elemental composition of the recycled P-fertilizers, while the process of their production was described in separate articles [61,62].

Table 1. Recycled fertilizers tested in the experiments.

\begin{tabular}{cccc}
\hline Fertilizer Symbol & Raw Material & Bacteria & Form \\
\hline $\mathrm{A}_{\mathrm{s}} B m$ & sewage sludge ash (SSA) & Bacillus megaterium & suspension \\
$\mathrm{B}_{\mathrm{s}} B m$ & bones & Bacillus megaterium & suspension \\
$\mathrm{A}_{\mathrm{g}} A f$ & SSA & Acidithiobacillus ferrooxidans & granules \\
$\mathrm{AB}_{\mathrm{g}} A f$ & SSA + bones & Acidithiobacillus ferrooxidans & granules \\
$\mathrm{AB}$ & SSA + bones & no bacteria & granules \\
$\mathrm{AB}_{\mathrm{g}} B m$ & SSA + bones & Bacillus megaterium & granules \\
\hline
\end{tabular}

Recycled fertilizers were compared with superphosphate (SP). According to the commercial information provided on the label, this universal, concentrated P-fertilizer contains $40 \% \mathrm{P}_{2} \mathrm{O}_{5}(17.4 \% \mathrm{P}), 10 \% \mathrm{CaO}(7.15 \% \mathrm{Ca}), 5 \% \mathrm{SO} 3(2 \% \mathrm{~S})$, and microelements (B, Co, Cu, Fe, $\mathrm{Mn}, \mathrm{Mo}$, and $\mathrm{Zn}$ ). According to an inductively coupled plasma-optical emission spectrometer (ICP-OES) analysis (the Chemical Laboratory of Multielemental Analysis at Wrocław University of Science and Technology accredited by ILAC-MRA and the Polish Center for Accreditation according to PN-EN ISO/IEC 17025 [63]; $\mathrm{n}=3)$, apart from P $(17.09 \%)$, this 
conventional fertilizer contained $25.57 \mathrm{mg} \cdot \mathrm{kg}^{-1} \mathrm{As}, 15.66 \mathrm{mg} \cdot \mathrm{kg}^{-1} \mathrm{Cd}, 186.1 \mathrm{mg} \cdot \mathrm{kg}^{-1} \mathrm{Cr}$, $22.35 \mathrm{mg} \cdot \mathrm{kg}^{-1} \mathrm{Cu}, 44.29 \mathrm{mg} \cdot \mathrm{kg}^{-1} \mathrm{Ni}, 10.43 \mathrm{mg} \cdot \mathrm{kg}^{-1} \mathrm{~Pb}$, and $230 \mathrm{mg} \cdot \mathrm{kg}^{-1} \mathrm{Zn}$.

All P-fertilizers used in the experiments met the requirements of Polish and EU regulations for mineral fertilizers (Table 3).

Table 2. Elemental composition of recycled P-fertilizers ${ }^{1}$.

\begin{tabular}{cccccccc}
\hline Element & Unit & $\mathbf{A}_{\mathbf{s}} \mathbf{B} \boldsymbol{m}$ & $\mathbf{B}_{\mathbf{s}} \mathbf{B} \boldsymbol{m}$ & $\mathbf{A}_{\mathbf{g}} \boldsymbol{A f}$ & $\mathbf{A B}_{\mathbf{g}} \boldsymbol{A f}$ & $\mathbf{A B}_{\mathbf{g}}$ & $\mathbf{A B}_{\mathbf{g}} \mathbf{B} \boldsymbol{m}$ \\
\hline $\mathrm{P}$ & $\%$ mass & 0.176 & 0.259 & 9.24 & 7.50 & 6.10 & 5.87 \\
$\mathrm{~N}$ & & 0.255 & 0.350 & 0.530 & 3.190 & 3.82 & 3.14 \\
$\mathrm{~K}$ & & 0.487 & 0.217 & 0.963 & 0.727 & 0.846 & 0.772 \\
$\mathrm{Ca}$ & & 0.694 & 0.373 & 12.513 & 12.012 & 11.369 & 10.725 \\
$\mathrm{Mg}$ & & 0.119 & 0.009 & 2.442 & 1.176 & 1.296 & 1.188 \\
$\mathrm{~S}$ & & 0.055 & 0.046 & 1.38 & 1.50 & 2.28 & 1.91 \\
$\mathrm{Na}$ & & 0.049 & 0.037 & 0.338 & 0.569 & 0.382 & 0.366 \\
$\mathrm{C}$ & & 0.590 & 1.650 & 6.71 & 23.6 & 17.6 & 16.1 \\
\hline $\mathrm{Fe}$ & \multirow{2}{*}{$\mathrm{kg}^{-1}$} & 1.679 & 0.022 & 33.0 & 15.1 & 15.4 & 14.4 \\
$\mathrm{Al}$ & & 1.774 & 0.008 & 24.4 & 13.9 & 12.8 & 11.3 \\
$\mathrm{Zn}$ & & 0.117 & 0.007 & 2.00 & 1.18 & 1.75 & 1.56 \\
\hline $\mathrm{As}$ & \multirow{2}{*}{$\mathrm{mgg}^{-1}$} & $<0.5$ & $<0.5$ & 4.35 & 2.55 & 26.5 & $<0.5$ \\
$\mathrm{Cd}$ & & 0.274 & 0.01 & 0.43 & 0.24 & 0.38 & 0.84 \\
$\mathrm{Cr}$ & & 5.94 & 0.218 & 135 & 60.0 & 114 & 94.7 \\
$\mathrm{Cu}$ & & 55.0 & 0.433 & 880 & 398 & 470 & 444 \\
$\mathrm{Ni}$ & & 2.45 & 0.212 & 57.7 & 25.1 & 52.3 & 44.3 \\
$\mathrm{~Pb}$ & & 10.4 & 1.04 & 21.6 & 11.2 & 34.0 & 14.5 \\
\hline
\end{tabular}

${ }^{1}$ Analyses performed at the Chemical Laboratory of Multielemental Analysis at Wrocław University of Science and Technology accredited by ILAC-MRA and the Polish Center for Accreditation according to PN-EN ISO/IEC $17025[63] ; \mathrm{n}=3$.

Recycled fertilizers were compared with superphosphate (SP). According to the commercial information provided on the label, this universal, concentrated P-fertilizer contains $40 \% \mathrm{P}_{2} \mathrm{O}_{5}(17.4 \% \mathrm{P}), 10 \% \mathrm{CaO}(7.15 \% \mathrm{Ca}), 5 \% \mathrm{SO} 3(2 \% \mathrm{~S})$, and microelements (B, Co, Cu, Fe, $\mathrm{Mn}, \mathrm{Mo}$, and $\mathrm{Zn})$. According to an inductively coupled plasma-optical emission spectrometer (ICP-OES) analysis (the Chemical Laboratory of Multielemental Analysis at Wrocław University of Science and Technology accredited by ILAC-MRA and the Polish Center for Accreditation according to PN-EN ISO/IEC 17025 [63]; $\mathrm{n}=3)$, apart from P $(17.09 \%)$, this conventional fertilizer contained $25.57 \mathrm{mg} \cdot \mathrm{kg}^{-1} \mathrm{As}, 15.66 \mathrm{mg} \cdot \mathrm{kg}^{-1} \mathrm{Cd}, 186.1 \mathrm{mg} \cdot \mathrm{kg}^{-1} \mathrm{Cr}$, $22.35 \mathrm{mg} \cdot \mathrm{kg}^{-1} \mathrm{Cu}, 44.29 \mathrm{mg} \cdot \mathrm{kg}^{-1} \mathrm{Ni}, 10.43 \mathrm{mg} \cdot \mathrm{kg}^{-1} \mathrm{~Pb}$, and $230 \mathrm{mg} \cdot \mathrm{kg}^{-1} \mathrm{Zn}$.

All P-fertilizers used in the experiments met the requirements of Polish and EU regulations for mineral fertilizers (Table 3).

Table 3. PTE limit values in mineral fertilizers according to Polish and EU regulations, $\mathrm{mg} \cdot \mathrm{kg}^{-1} \mathrm{DM}$.

\begin{tabular}{ccccccccc}
\hline Regulation & As & $\mathbf{C d}$ & $\mathbf{C r}$ & $\mathbf{C u}$ & $\mathbf{H g}$ & $\mathbf{N i}$ & $\mathbf{P b}$ & $\mathbf{Z n}$ \\
\hline Poland [64] & 50 & 50 & n.s. & n.s. & 2.0 & n.s. & 140 & n.s. \\
EU [24] & 40 & $60^{1}$ & n.s. & n.s. & 1.0 & 100 & 120 & n.s. \\
\hline
\end{tabular}

${ }^{1}$ per $1 \mathrm{~kg} \mathrm{P}_{2} \mathrm{O}_{5} ;$ n.s.- - not standardized.

\subsection{Experimental Design and Agronomic Management}

Recycled fertilizers were tested in four field experiments conducted in the years 2014 2016 (Table 4). Common wheat (Triticum aestivum ssp. vulgare Mac Key), winter or spring, was adopted as a test plant. In each experiment, the reference treatments for the recycled fertilizers were treatments with superphosphate (SP) fertilization and treatment without phosphorus fertilization (No P). 
Table 4. Field experiments conducted.

\begin{tabular}{ccccccc}
\hline Experiment & Year & Test Plant & $\begin{array}{c}\text { Recycled } \\
\text { Fertilizers }\end{array}$ & $\begin{array}{c}\text { Reference } \\
\text { Treatments }\end{array}$ & P Doses, kg.ha-1 & Plant Protection (PP) \\
\hline I & 2014 & spring wheat & $\mathrm{A}_{\mathrm{s}} B m, \mathrm{~B}_{\mathrm{s}} B m$ & No P, SP & 21 & $\mathrm{PP}-$ \\
II & 2015 & spring wheat & $\mathrm{A}_{\mathrm{s}} B m$ & No P, SP & $17.6,26.4,35.2$ & $\mathrm{PP}-, \mathrm{PP}+$ \\
III & 2015 & winter wheat & $\mathrm{A}_{\mathrm{g}} A f, \mathrm{AB}_{\mathrm{g}} A f$ & No P, SP & $17.6,26.4,35.2$ & $\mathrm{PP}+$ \\
IV & 2016 & winter wheat & $\mathrm{AB}_{\mathrm{g}}, \mathrm{AB}_{\mathrm{g}} B m$ & No P, SP & $17.6,26.4,35.2$ & $\mathrm{PP}+$ \\
\hline
\end{tabular}

In Experiment I, all P-fertilizers were applied at a $\mathrm{P}$ dose of $21 \mathrm{~kg} \cdot \mathrm{ha}^{-1}$, and in Experiments II-IV, three different $P$ levels were established: 17.6, 26.4, and $35.2 \mathrm{~kg} \cdot \mathrm{ha}^{-1}$. Suspension fertilizers were applied by the large-drop sprinkling of the soil, and solid fertilizers were manually scattered on the soil surface. The fertilizers were mixed with the soil by harrowing. In Experiment I, plant protection against agrophages (weeds, fungal pathogens, and pests) was not used (PP-); in Experiment II, two levels of plant protection were adopted-without protection ( $\mathrm{PP}-$ ) and with full protection $(\mathrm{PP}+)$; and in Experiments III and IV, full plant protection ( $\mathrm{PP}+$ ) was practiced. Other agricultural data for the experiments are shown in Table 5. Fertilization and other agrotechnical treatments were adjusted to the species requirements of the test plant and soil conditions and were consistent with the standards of good agricultural practice. Additionally, pesticides were applied according to the recommendations of the Institute of Plant Protection-National Research Institute in Poznan (Poland). All wheat cultivars used were assigned to the region according to Research Centre for Cultivar Testing (COBORU) in Słupia Wielka (Poland) recommendations.

Table 5. Basic agricultural data for the experiments.

\begin{tabular}{|c|c|c|c|c|}
\hline \multirow{2}{*}{ Item } & \multicolumn{4}{|c|}{ Experiment } \\
\hline & I & II & III & IV \\
\hline Wheat cultivar & Trappe & Monsun & Julius & Julius \\
\hline Previous crop & spring barley & cereal-legume mixture & winter rape & winter rape \\
\hline Soil tillage system & plough tillage & plough tillage & plough tillage & plough tillage \\
\hline \multicolumn{5}{|l|}{ Fertilization } \\
\hline \multirow[t]{2}{*}{$-\mathrm{K}, \mathrm{kg} \cdot \mathrm{ha}^{-1}$} & 99.6 & 83 & 83 & 83 \\
\hline & potassium chloride & potassium chloride & potassium chloride & potassium chloride \\
\hline \multirow[t]{2}{*}{$-\mathrm{N}, \mathrm{kg} \cdot \mathrm{ha}^{-1}$} & 100 & 110 & 130 & 120 \\
\hline & ammonium sulphate & ammonium sulphate & ammonium sulphate & ammonium sulphate \\
\hline \multicolumn{5}{|l|}{ Plant protection } \\
\hline \multirow{3}{*}{$\begin{array}{l}\text { - herbicides } \\
\text { - fungicides }\end{array}$} & & $\mathrm{MCPA}^{1}$ & 2.4-D + florasulam & 2.4-D + florasulam \\
\hline & & $\begin{array}{c}\text { azoxystrobin }^{1} \\
+ \text { propiconazole }\end{array}$ & $\begin{array}{c}\text { fenpropimorph }+ \\
\text { epoxiconazole }+ \\
\text { metrafenon }\end{array}$ & $\begin{array}{c}\text { fenpropimorph }+ \\
\text { epoxiconazole }+ \\
\text { metrafenon }\end{array}$ \\
\hline & & cyproconazole ${ }^{1}$ & $\begin{array}{l}\text { fluksapyroksad + } \\
\text { piraklostrobina }+ \\
\text { epoxiconazole }\end{array}$ & $\begin{array}{l}\text { fluksapyroksad }+ \\
\text { piraklostrobina }+ \\
\text { epoxiconazole }\end{array}$ \\
\hline - insecticides & & lambda-cyhalothrin ${ }^{1}$ & deltamethrin & deltamethrin \\
\hline - growth regulators & & & trinexapac ethyl & trinexapac ethyl \\
\hline Sowing date & 25.04 .2014 & 9.04 .2015 & 2.10 .2014 & 15.10 .2015 \\
\hline Harvest date & 11.08.2014 & 11.08.2015 & 5.08 .2015 & 9.08 .2016 \\
\hline
\end{tabular}

${ }^{1}$ applied only on plots with full plant protection (PP+).

Experiments I, III, and IV were established in a randomized block design and Experiment II in a parallel strip design. In each experiment, individual experimental treatments were executed in four replications (on four experimental plots of $20 \mathrm{~m}^{2}$ each). 


\subsection{Study Site, Soil and Meteorological Conditions}

The experiments with P-fertilizers were conducted at the Production and Experimental Station 'Bałcyny' Sp. z o.o. in Bałcyny (north-eastern Poland, Warmińsko-Mazurskie Province, $53^{\circ} 35^{\prime} 49^{\prime \prime} \mathrm{N}, 19^{\circ} 51^{\prime} 20^{\prime \prime} \mathrm{E}, 136.9 \mathrm{~m}$ above sea level) (Figure 1). The site is characterized by a temperate climate and geomorphological features that were predominantly formed during the Vistulian glaciation. The lowest air temperatures here are usually recorded in January and the highest in July. The average air relative humidity in the region varies from $71 \%$ in June to $90 \%$ in December [65]. The growing season lasts, on average, 215 days and falls in the months April to October [66].

In each experiment, wheat was grown in soil suitable for the species requirements (Table 6). The PTE content of the soil before the start of each experiment was within the range, deemed natural, and did not exceed the limits for agricultural use in Poland (see data and reference in Table 7).

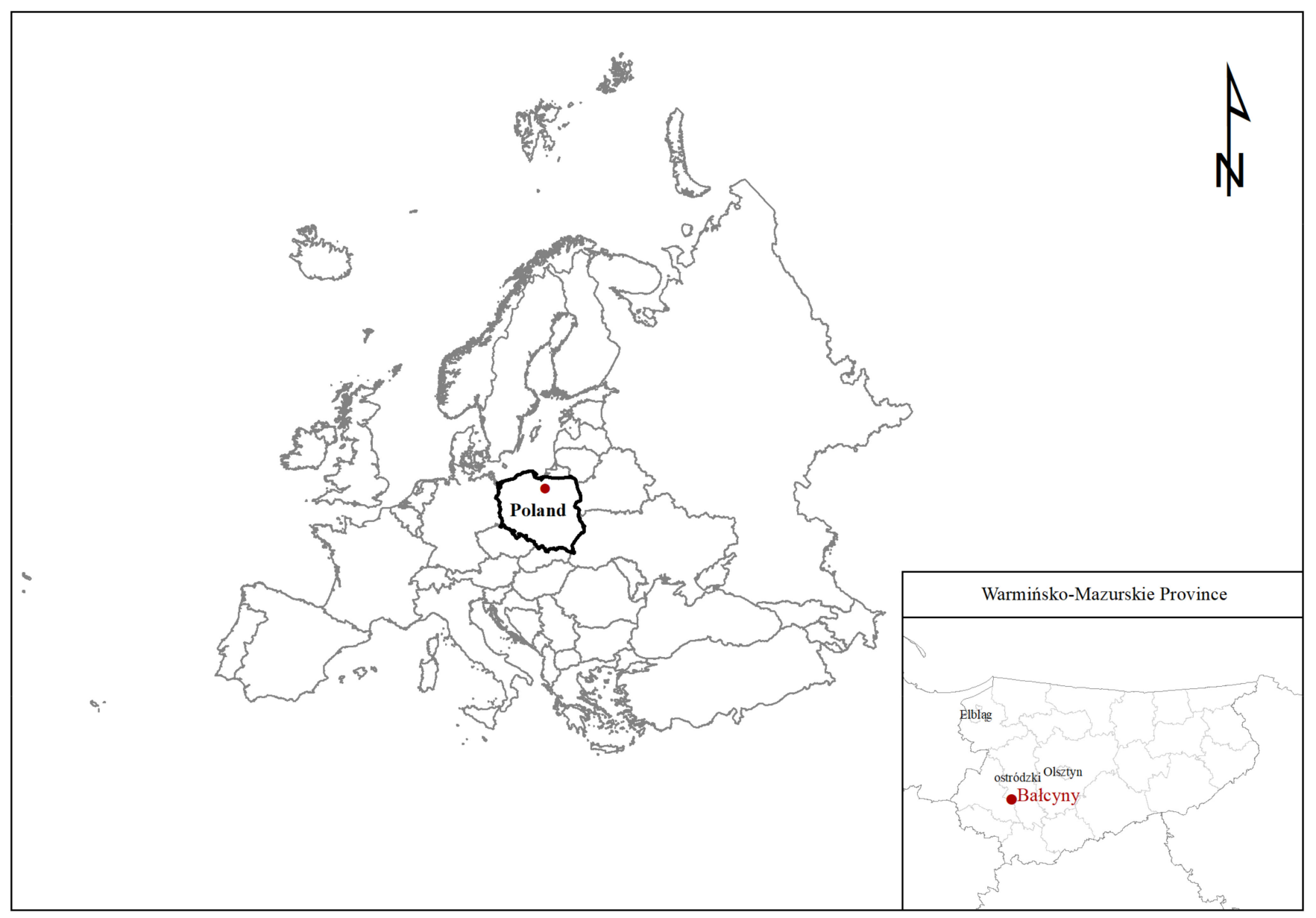

Figure 1. Study site location.

Table 6. Soil characteristic before the start of the experiments.

\begin{tabular}{|c|c|c|c|c|}
\hline \multirow{2}{*}{ Properties } & \multicolumn{4}{|c|}{ Experiment } \\
\hline & $I(n=16)$ & $\mathrm{II}(\mathrm{n}=56)$ & III $(n=40)$ & IV $(n=40)$ \\
\hline Soil type ${ }^{1}$ & Luvisols & Luvisols & Luvisols & Luvisols \\
\hline Soil texture ${ }^{2}$ & sandy clay loam & sandy loam & sandy loam & sandy loam \\
\hline $\mathrm{pH}$ in $\mathrm{KCl}^{3}$ & 6.23 & 5.32 & 5.51 & 5.23 \\
\hline
\end{tabular}


Table 6. Cont.

\begin{tabular}{|c|c|c|c|c|c|}
\hline \multirow{2}{*}{\multicolumn{2}{|c|}{ Properties }} & \multicolumn{4}{|c|}{ Experiment } \\
\hline & & I $(n=16)$ & II $(n=56)$ & III $(n=40)$ & IV $(n=40)$ \\
\hline \multirow{12}{*}{ Total, ${ }^{4}$} & $\mathrm{C}, \mathrm{g} \cdot \mathrm{kg}^{-1}$ & 8.31 & 8.90 & 8.87 & 7.15 \\
\hline & $\mathrm{N}, \mathrm{g} \cdot \mathrm{kg}^{-1}$ & 1.30 & 1.35 & 1.36 & 1.09 \\
\hline & $\mathrm{P}, \mathrm{mg} \cdot \mathrm{kg}^{-1}$ & 574 & 566 & 433 & 548 \\
\hline & $\mathrm{K}, \mathrm{mg} \cdot \mathrm{kg}^{-1}$ & 2979 & 2895 & 3210 & 3304 \\
\hline & $\mathrm{Mg}, \mathrm{mg} \cdot \mathrm{kg}^{-1}$ & 2070 & 2007 & 2253 & 2195 \\
\hline & $\mathrm{Cd}, \mathrm{mg} \cdot \mathrm{kg}^{-1}$ & $0.025(0.365)$ & $0.292(0.827)$ & 0.309 (1.083) & $0.133(0.553)$ \\
\hline & $\mathrm{Pb}, \mathrm{mg} \cdot \mathrm{kg}^{-1}$ & 4.855 (13.198) & 7.959 (25.099) & 7.059 (22.895) & $2.297(18.180)$ \\
\hline & As, $\mathrm{mg} \cdot \mathrm{kg}^{-1}$ & $2.012(8.388)$ & $0.574(3.013)$ & $<0.5(<0.5)$ & $2.067(8.390)$ \\
\hline & $\mathrm{Cu}, \mathrm{mg} \cdot \mathrm{kg}^{-1}$ & $10.66(14.97)$ & $10.28(14.92)$ & $11.90(19.44)$ & $9.113(10.860)$ \\
\hline & $\mathrm{Cr}, \mathrm{mg} \cdot \mathrm{kg}^{-1}$ & $19.96(23.72)$ & $19.60(23.95)$ & $20.85(32.07)$ & $23.34(28.37)$ \\
\hline & $\mathrm{Ni}, \mathrm{mg} \cdot \mathrm{kg}^{-1}$ & $7.16(11.25)$ & $8.53(14.78)$ & 8.05 (18.27) & $10.69(15.71)$ \\
\hline & $\mathrm{Zn}, \mathrm{mg} \cdot \mathrm{kg}^{-1}$ & $33.60(43.52)$ & $60.30(78.80)$ & $51.08(64.98)$ & 41.69 (56.22) \\
\hline
\end{tabular}

\footnotetext{
${ }^{1}$ According to World reference base for soil resources 2014 [67]; ${ }^{2}$ based on agricultural map (1:5000) held by the Production and Experimental Station 'Bałcyny' Sp. z o.o. in Bałcyny (Bałcyny 15, 14-100 Ostróda, Poland); ${ }^{3}$ determined by the potentiometric method [68]; ${ }^{4}$ determined as described in Section 2.5 , average values, maximum values in brackets.
}

Table 7. Reference values for PTE of the soil and plants, $\mathrm{mg} \cdot \mathrm{kg}^{-1} \mathrm{DM}$.

\begin{tabular}{|c|c|c|c|c|c|}
\hline Content & As & $\mathrm{Cr}$ & $\mathrm{Cu}$ & $\mathrm{Ni}$ & $\mathrm{Zn}$ \\
\hline \multicolumn{6}{|c|}{ In Soil } \\
\hline Geochemical background for Poland $[69,70]$ & $2-13$ & $2-64$ & $0.4-23.5$ & $0.5-28.5$ & $5.0-59$ \\
\hline In surface level of mineral soils in Poland [71] & $0.6-10$ & $5-100$ & $0.5-25$ & $0.5-60$ & $10-225$ \\
\hline \multicolumn{6}{|l|}{ Permissible in Poland in arable land [72] } \\
\hline$-\mathrm{I}^{1}$ & 10 & 150 & 100 & 100 & 300 \\
\hline- II & 20 & 300 & 150 & 150 & 500 \\
\hline$-\mathrm{III}$ & 50 & 500 & 300 & 300 & 1000 \\
\hline \multicolumn{6}{|l|}{ Monitoring of arable soils [73] } \\
\hline - Poland & $0.73-20.7$ & $2.4-49.1$ & $1.2-320.1$ & $1.0-71.1$ & $5.9-6668.3$ \\
\hline-- average & 3.63 & 11.0 & 10.3 & 9.8 & 78.8 \\
\hline-- median & 2.77 & 8.7 & 6.2 & 6.1 & 32.0 \\
\hline- region $^{2}$ & $1.52-3.87$ & $4.5-30.6$ & $3.3-17.1$ & $2.6-29.8$ & $19.4-61.9$ \\
\hline \multicolumn{6}{|c|}{ In Plant } \\
\hline Sufficient or normal [4] & $1-1.7$ & $0.1-0.5$ & $5-30$ & $0.1-5$ & $27-150$ \\
\hline Excessive or toxic [4] & $5-20$ & $5-30$ & $20-100$ & $10-100$ & $100-400$ \\
\hline Average in cereal grain [71] & $0.03-0.6$ & $0.003-0.4$ & $2.6-6$ & $0.1-0.5$ & $15-60$ \\
\hline \multicolumn{6}{|l|}{ Permissible in Poland } \\
\hline - in cereal grain $[74]^{3}$ & 0.20 & n.s. & n.s. & n.s. & n.s. \\
\hline - in feed materials of plant origin $[75,76]$ & 2 & n.s. & n.s. & n.s. & n.s. \\
\hline \multicolumn{6}{|l|}{ Other standards for food grain } \\
\hline$-\mathrm{FAO} / \mathrm{WHO}[77]$ & $0.35(0.2)^{4}$ & n.s. & n.s. & n.s. & n.s. \\
\hline - EU [78] & $0.1-0.25^{5}$ & n.s. & n.s. & n.s. & n.s. \\
\hline - PR of China [79] & $0.5(0.2)^{6}$ & 0.1 & n.s. & n.s. & n.s. \\
\hline \multicolumn{6}{|l|}{$\begin{array}{l}\text { Suggested maximum values in plant material } \\
\qquad[80,81]\end{array}$} \\
\hline - for food purposes & n.i. & n.i. & 20 & 10 & 50 \\
\hline - for feed purposes & n.i. & 20 & $25-50$ & 50 & 100 \\
\hline
\end{tabular}

${ }^{1}$ Sub-groups of arable land depending on soil compaction and $\mathrm{pH}^{2}{ }^{2}$ range for 4 measurement points (villages) located geographically closest to the test site (Bałcyny); ${ }^{3}$ regulation repealed, no new; ${ }^{4}$ for inorganic As in rice husked or polished (value in brackets); ${ }^{5}$ for inorganic As in rice depending on its preparation and intended use; ${ }^{6}$ value for rice in brackets; n.s.—not standardized; n.i.—no information.

The precipitation and air temperatures during the growing seasons were not favorable to the wheat plants (Table 8). In Experiments I-III, the growing seasons for the test plants (spring and winter wheat) tended to be very dry (rainfall deficits in May and July 2014 and in May and June 2015), while in Experiment IV, winter wheat developed under wet season conditions with excessive rainfall in July 2016. The water content of the soil may alter the PTE 
availability to plants [82]. Moreover, heavy rainfall may also result in the leaching of PTE from the surface layers of the soil and in their accumulation in depressions in the ground [83].

Table 8. Precipitation and air temperature during the study period according to the Meteorological Station in Bałcyny [84].

\begin{tabular}{|c|c|c|c|c|c|c|c|c|c|c|c|c|c|}
\hline \multirow{2}{*}{ Year } & \multirow{2}{*}{ Days } & \multicolumn{12}{|c|}{ Month } \\
\hline & & I & II & III & IV & V & VI & VII & VIII & IX & $X$ & XI & XII \\
\hline & & \multicolumn{12}{|c|}{ Precipitation, mm } \\
\hline \multirow{4}{*}{2014} & $1-10$ & & & & 16.7 & 15.0 & 15.7 & 11.8 & 37.3 & 12.6 & 0.0 & 9.5 & 0.0 \\
\hline & $11-20$ & & & & 5.6 & 2.3 & 21.5 & 8.6 & 6.8 & 0.0 & 20.8 & 6.2 & 12.8 \\
\hline & $21-31$ & & & & 3.8 & 17.6 & 35.0 & 0.0 & 15.1 & 18.2 & 0.5 & 5.5 & 43.8 \\
\hline & Total & & & & 26.1 & 34.9 & 72.2 & 20.4 & 59.2 & 30.8 & 21.3 & 21.2 & 56.6 \\
\hline \multirow{4}{*}{2015} & $1-10$ & 20.7 & 5.7 & 19.2 & 8.1 & 7.2 & 0.1 & 13.6 & 2.0 & 44.0 & 0.0 & 30.7 & 9.3 \\
\hline & $11-20$ & 0.4 & 2.0 & 0.0 & 10.9 & 17.7 & 11.5 & 22.0 & 0.0 & 6.8 & 18.6 & 39.3 & 26.4 \\
\hline & $21-31$ & 7.4 & 1.1 & 26.8 & 4.4 & 0.5 & 31.4 & 35.4 & 11.0 & 0.4 & 2.2 & 10.8 & 44.7 \\
\hline & Total & 28.5 & 8.8 & 46.0 & 23.4 & 25.4 & 43.0 & 71.0 & 13.0 & 51.2 & 20.8 & 80.8 & 80.4 \\
\hline \multirow{4}{*}{2016} & $1-10$ & 0.3 & 11.8 & 0.6 & 4.8 & 7.5 & 12.1 & 39.6 & 54.5 & 7.5 & 65.1 & 39.9 & 41.4 \\
\hline & $11-20$ & 9.0 & 23.7 & 7.0 & 19.2 & 53.7 & 28.1 & 34.0 & 10.4 & 1.2 & 9.2 & 27.7 & 19.2 \\
\hline & $21-31$ & 19.4 & 15.0 & 12.9 & 9.1 & 9.6 & 26.1 & 65.0 & 7.0 & 8.4 & 22.0 & 10.6 & 17.2 \\
\hline & Total & 28.7 & 50.5 & 20.5 & 33.1 & 70.8 & 66.3 & 138.6 & 71.9 & 17.1 & 96.3 & 78.2 & 77.8 \\
\hline \multirow[t]{2}{*}{ 1981-2010 } & Total & 30.1 & 23.1 & 30.7 & 29.8 & 62.3 & 72.9 & 81.2 & 70.6 & 56.2 & 51.2 & 46.1 & 42.6 \\
\hline & & \multicolumn{12}{|c|}{ Air temperature, ${ }^{\circ} \mathrm{C}$} \\
\hline \multirow{4}{*}{2014} & $1-10$ & & & & 7.0 & 8.9 & 16.5 & 20.5 & 22.2 & 15.0 & 11.3 & 8.5 & -1.7 \\
\hline & $11-20$ & & & & 8.5 & 13.3 & 14.2 & 19.6 & 17.2 & 17.0 & 12.2 & 4.7 & 3.5 \\
\hline & $21-31$ & & & & 12.9 & 17.1 & 13.8 & 22.8 & 14.6 & 11.6 & 5.4 & 0.0 & -3.2 \\
\hline & Average & & & & 9.5 & 13.3 & 14.8 & 21.0 & 17.9 & 14.5 & 9.5 & 4.4 & -0.6 \\
\hline \multirow{4}{*}{2015} & $1-10$ & 0.0 & -1.8 & 4.2 & 4.1 & 11.7 & 15.7 & 19.8 & 23.3 & 15.2 & 7.9 & 6.3 & 4.7 \\
\hline & $11-20$ & 2.7 & -0.1 & 4.7 & 7.1 & 11.6 & 15.9 & 16.9 & 21.1 & 15.9 & 6.0 & 7.9 & 3.1 \\
\hline & $21-31$ & -0.9 & 3.3 & 4.9 & 10.4 & 13.0 & 15.5 & 17.4 & 19.5 & 11.6 & 6.0 & 1.2 & 3.5 \\
\hline & Average & 0.6 & 0.3 & 4.6 & 7.2 & 12.1 & 15.7 & 18.0 & 21.3 & 14.2 & 6.6 & 5.1 & 3.8 \\
\hline \multirow{4}{*}{2016} & $1-10$ & -8.4 & 4.1 & 2.9 & 10.3 & 14.1 & 16.4 & 17.5 & 17.7 & 17.5 & 9.0 & 2.7 & 1.9 \\
\hline & $11-20$ & -4.3 & 2.0 & 2.2 & 9.1 & 11.8 & 16.3 & 18.1 & 15.6 & 15.1 & 5.7 & 2.7 & -0.3 \\
\hline & $21-31$ & 0.7 & 2.1 & 5.5 & 6.9 & 18.5 & 21.3 & 19.9 & 19.3 & 11.7 & 6.1 & 2.1 & 1.4 \\
\hline & Average & -3.8 & 2.7 & 3.6 & 8.8 & 14.9 & 18.0 & 18.5 & 17.6 & 14.7 & 6.9 & 2.5 & 1.0 \\
\hline 1981-2010 & Average & -2.4 & -1.6 & 1.8 & 7.7 & 13.2 & 15.8 & 18.3 & 17.7 & 13.0 & 8.1 & 2.8 & -1.0 \\
\hline
\end{tabular}

\subsection{Sampling \\ 2.4.1. Soil}

Soil from the 0-0.30 $\mathrm{m}$ layer was sampled before the start of each experiment and after wheat harvest, using a hand-held twisting probe (Egner's soil sampler). Sampling was performed at 30 evenly spaced points in each plot, and a total of approximately $1 \mathrm{~kg}$ of soil was taken from an individual plot. The collected field-fresh soil samples were air-dried at room temperature $\left(\sim 22^{\circ} \mathrm{C}\right)$ for several (5-7) days, thoroughly mixed, and sieved. Portions of approximately $300 \mathrm{~g}$ were then delivered to the accredited chemical laboratory (the Chemical Laboratory of Multielemental Analysis at Wrocław University of Science and Technology, Poland, accredited by ILAC-MRA and the Polish Center for Accreditation according to PN-EN ISO/IEC 17025 [63], Accreditation Certificate No. AB 696) for elemental analysis.

\subsubsection{Wheat Grain}

Grain samples weighing approximately $1 \mathrm{~kg}$ were taken from the volume resulting after combine harvesting from each plot. Out of these samples, portions of approximately $200 \mathrm{~g}$ of grain were weighed, and after cleaning from impurities and weed seeds, sent for chemical analyses. 


\subsubsection{Wheat Straw}

Directly before harvest, wheat plants were picked up manually from two 1 meter-long rows of each plot. The wheat roots were then cut off at a height matching the combine harvester mowing height, and the spikes were removed. Straw (i.e., wheat stems with leaves) was cut into pieces of approximately $10 \mathrm{~cm}$ in length. The prepared samples were dried at room temperature for several days, and a portion of $50 \mathrm{~g}$ was then weighed from each sample and sent for chemical analyses.

\subsubsection{Weeds}

Weed samples were collected from a randomly designated $0.25 \mathrm{~m}^{2}(0.5 \mathrm{~m} \times 0.5 \mathrm{~m}$ frame) area from each plot prior to wheat harvest. Weed roots were cut off and the aboveground biomass of weeds was dried at room temperature for several days. Afterwards, the samples in their entirety (different mass) were passed for chemical analyses.

\subsubsection{Post-Harvest Residues}

Post-harvest residues, i.e., wheat roots and bottom stem segments (stubble), and weed remnants left in the field after combine harvesting were sampled from each plot after wheat harvest. Soil columns of $0.40 \mathrm{~m}^{2}$ and $0.30 \mathrm{~m}$ depth were dug up and then washed on sieves to remove soil particles. The plant material samples prepared in this way were dried at room temperature for several days and sent in their entirety for chemical analysis.

\subsection{Chemical Analyses}

The total soil contents of carbon $(\mathrm{C})$ and nitrogen $(\mathrm{N})$ were determined by Vario Macro Cube Elementar (C, H, N) analyzer (Elementar Analysensysteme, Langenselbold, Germany). As a standard solution, D-phenylalanine ( $\mathrm{C}=65.44 \%$; $=8.48 \%)$ was used.

An inductively coupled plasma-optical emission spectrometer (ICP-OES with a pneumatic nebulizer with an axial view-iCAP Duo Thermo Scientific, USA) was used to determine the contents of other elements in the soil and plant material. The Teflon vessels (microwave oven Milestone MLS-1200) and $5 \mathrm{~mL}$ of concentrated $65 \mathrm{mg} \cdot \mathrm{kg}^{-1} \mathrm{HNO}_{3}$ Suprapur ${ }^{\mathrm{TM}}$ (Merck) in the case of plant samples and with $10 \mathrm{~mL}$ of aqua regia in the case of soil samples were used to digest an appropriate mass $(0.5 \mathrm{~g})$ of sample materials (plant or soil). Then, all samples were diluted to $50 \mathrm{~mL}$. The obtained samples were subjected to multi-elemental analyses using ICP-OES. The determination of PTE content was carried out with all the principles of measurement traceability, and certified reference materials were used to check the quality and metrological traceability. The detection levels for $\mathrm{P}, \mathrm{K}, \mathrm{Mg}$, As, $\mathrm{Cd}, \mathrm{Cr}, \mathrm{Cu}, \mathrm{Ni}, \mathrm{Pb}$, and $\mathrm{Zn}$ for the soil material were 3.59, 2.55, 1.17, 0.5, 0.01, 0.035, 0.27, $0.25,0.15$, and $0.32 \mathrm{mg} \cdot \mathrm{kg}^{-1}$, respectively, and for the plant material, the detection levels for As, $\mathrm{Cr}, \mathrm{Cu}, \mathrm{Ni}$, and $\mathrm{Zn}$ were $0.05,0.005,0.04,0.002$, and $0.013 \mathrm{mg} \cdot \mathrm{kg}^{-1}$, respectively [85].

\subsection{Calculations and Statistical Analysis}

Based on the elemental composition of fertilizers (As content below the detection level (DL) replaced by $0.5 \mathrm{mg} \cdot \mathrm{kg}^{-1}$ ) (Table 1), and assuming that a dry soil from the 0-30 cm-deep layer and 1 ha area weighs $4500 \mathrm{t}$, the PTE input per 1 ha with fertilizers applied at different $\mathrm{P}$ doses was calculated, as well as the potential increase in soil PTE content (per $1 \mathrm{~kg}$ of soil).

The data on PTE content in soil and plant biomass were processed using an analysis of variance ANOVA (when its assumptions were met) or the alternative Kruskal-Wallis test (when ANOVA assumptions were not met). The Shapiro-Wilk W test and Levene's test were used to verify the normality of distribution of variables and the homogeneity of variance, respectively. Duncan's test or a multiple comparisons test was then applied to assess differences between objects. In statistical calculations, the PTE contents below the detection level (DL) were replaced by values equal to the DL. For each experiment, the median (Me) and the maximum value (Max) were determined. The calculations were performed using Statistica 13.3 software [86]. 


\section{Results and Discussion}

\subsection{PTE Input from Fertilizers to Soil}

The PTE presence in the tested P-fertilizers (Table 1) suggests the possibility of their accumulation in soil due to fertilizer application, which should potentially become apparent in comparison to no P treatments. The amount of PTE introduced into the soil with P fertilizers per ha and the potential increase in soil PTE content are shown in Table 9. Considering the limit values for annual loads of certain PTE established by EC [87], these quantities should be qualified as very small, and the soil enrichment in PTE is negligible for statistical analysis (compare differences in [15]).

Table 9. PTE amounts introduced into soil with $\mathrm{P}$-fertilizers applied—range between the values for the lowest $\left(17.6 \mathrm{~kg} \cdot \mathrm{ha}^{-1}\right)$ and the highest $\left(35.2 \mathrm{~kg} \cdot \mathrm{ha}^{-1}\right) \mathrm{P}$ dose.

\begin{tabular}{|c|c|c|c|c|c|}
\hline \multirow{3}{*}{ Fertilizers } & As & $\mathrm{Cr}$ & $\mathrm{Cu}$ & $\mathbf{N i}$ & $\mathrm{Zn}$ \\
\hline & \multicolumn{5}{|c|}{ Input per 1 ha } \\
\hline & g & kg & kg & kg & kg \\
\hline $\mathrm{SP}^{1}$ & $2.633-5.265$ & $0.019-0.038$ & $0.002-0.005$ & $0.005-0.009$ & $0.025-0.049$ \\
\hline $\mathrm{A}_{\mathrm{s}} B m$ & $5.00-10.00^{2}$ & $0.059-0.119$ & $0.550-1.100$ & $0.025-0.049$ & $1.170-2.340$ \\
\hline $\mathrm{B}_{\mathrm{S}} B m$ & $3.398-6.795^{2}$ & $0.001-0.003$ & $0.003-0.006$ & $0.001-0.003$ & $0.048-0.095$ \\
\hline $\mathrm{A}_{\mathrm{g}} A f$ & $0.829-1.657$ & $0.026-0.051$ & $0.168-0.335$ & $0.011-0.022$ & $0.381-0.762$ \\
\hline $\mathrm{AB}_{\mathrm{g}} A f$ & $0.598-1.197$ & $0.014-0.028$ & $0.093-0.187$ & $0.006-0.012$ & $0.277-0.554$ \\
\hline $\mathrm{AB}_{\mathrm{g}}$ & $7.646-15.292$ & $0.033-0.066$ & $0.136-0.271$ & $0.015-0.030$ & $0.505-1.010$ \\
\hline $\mathrm{AB}_{\mathrm{g}} \mathrm{Bm}$ & $0.150-0.300$ & $0.028-0.057$ & $0.133-0.266$ & $0.013-0.027$ & $0.468-0.935$ \\
\hline \multirow[t]{2}{*}{ Limit values per year ${ }^{3}$} & n.s & $\begin{array}{c}\text { n.s. } \\
(0.04-12.0)^{4}\end{array}$ & 12 & 3 & 30 \\
\hline & \multicolumn{5}{|c|}{ Potential Increase in Soil Content, $\mu \mathrm{g} \mathrm{kg}^{-1}$ of Soil DM } \\
\hline SP & $0.59-1.17$ & $4.26-8.52$ & $0.51-1.02$ & $1.01-2.03$ & $5.47-10.94$ \\
\hline $\mathrm{A}_{\mathrm{s}} \mathrm{Bm}$ & $1.11-2.22^{2}$ & $13.20-26.40$ & $122.2-244.4$ & $5.44-10.89$ & $260.0-520$ \\
\hline $\mathrm{B}_{\mathrm{s}} B m$ & $0.76-1.51^{2}$ & $0.33-0.66$ & $0.65-1.31$ & $0.32-0.64$ & 10.6-21.14 \\
\hline $\mathrm{A}_{\mathrm{g}} A f$ & $0.18-0.37$ & $5.71-11.43$ & $37.2-74.5$ & $2.44-4.88$ & $84.7-169$ \\
\hline $\mathrm{AB}_{\mathrm{g}} A f$ & $0.13-0.27$ & $3.13-6.26$ & $20.8-41.5$ & $1.31-2.62$ & $61.5-123$ \\
\hline $\mathrm{AB}_{\mathrm{g}}$ & $1.70-3.40$ & $7.31-14.62$ & $30.1-60.3$ & $3.35-6.71$ & $112-224$ \\
\hline $\mathrm{AB}_{\mathrm{g}} \mathrm{Bm}$ & $0.03-0.07$ & $6.31-12.62$ & $29.6-59.2$ & $2.95-5.90$ & 104-208 \\
\hline
\end{tabular}

${ }^{1} \mathrm{SP}$-superphosphate, $\mathrm{A}_{\mathrm{s}} B m$-SSA-based suspension fertilizer with B. megaterium, $\mathrm{B}_{\mathrm{s}} B m$-bone-based suspension fertilizer with $B$. megaterium, $\mathrm{A}_{\mathrm{g}} A f$-SSA-based granular fertilizer with $A$. ferrooxidans, $\mathrm{AB}_{\mathrm{g}} A f$-SSA-bone-based granular fertilizer with $A$. ferrooxidans, $\mathrm{AB}_{\mathrm{g}}-$ SSA-bone-based granular fertilizer without PSM, $\mathrm{AB}_{\mathrm{g}} B m$-SSA-bone-based granular fertilizer with B. megaterium; ${ }^{2}$ potentially maximum values; ${ }^{3}$ according to Final Implementation Report for Directive 86/278/EEC on Sewage Sludge: 2013-2015 [87]; ${ }^{4}$ range of national limits set by 20 Member States, excluding Poland (no set limits) [87].

The recycled fertilizers tested tended to introduce more PTE than SP applied at the same dose. The exceptions were lower As inputs with $\mathrm{A}_{\mathrm{g}} A f, \mathrm{AB}_{\mathrm{g}} A f$, and $\mathrm{AB}_{\mathrm{g}} B m$ fertilizers, lower $\mathrm{Cr}$ and $\mathrm{Ni}$ inputs with $\mathrm{B}_{\mathrm{s}} \mathrm{Bm}$ and $\mathrm{Cr}$ with $\mathrm{AB}_{\mathrm{g}} A f$ fertilizers. It is noteworthy that even the relatively elevated amounts of $\mathrm{Cu}$ and $\mathrm{Zn}$ added to the soil with the recycled fertilizers were substantially lower than the doses of these micronutrients recommended for wheat [88].

\subsection{PTE in Soil}

The soil As, $\mathrm{Cr}, \mathrm{Cu}, \mathrm{Ni}$, and $\mathrm{Zn}$ contents in the conducted experiments (Table 10) met the ranges considered natural under Polish conditions and did not exceed permissible levels for arable lands (Table 7). The average and median values in the experiments were not very far from those determined for the whole country. Even the highest values fell within the geochemical background ranges and were at the levels typical for the region. For As, the median values in the experiments usually ranked below the detection level (an exception was Experiment IV). 
Table 10. PTE content in soil, $\mathrm{mg} \cdot \mathrm{kg}^{-1} \mathrm{DM}(\mathrm{n}=4)$.

\begin{tabular}{|c|c|c|c|c|c|c|c|c|}
\hline Experiment & P-Fertilizer & P-Dose, kg.ha-1 & Plant Protection & As & $\mathrm{Cr}$ & $\mathrm{Cu}$ & $\mathrm{Ni}$ & $\mathrm{Zn}$ \\
\hline \multirow{6}{*}{ I } & No P & 0 & \multirow[t]{4}{*}{$\mathrm{PP}-$} & 1.854 & 18.1 & $7.07 \downarrow$ & $5.31 \downarrow$ & $26.1 \downarrow$ \\
\hline & $\mathrm{SP}^{1}$ & 21 & & 2.096 & 19.6 & $8.20 \downarrow$ & $5.06 \downarrow$ & $28.2 \downarrow$ \\
\hline & $\mathrm{A}_{\mathrm{s}} B m$ & 21 & & 1.512 & 19.3 & $8.12 \downarrow$ & $6.03 \downarrow$ & $27.6 \downarrow$ \\
\hline & $\mathrm{B}_{\mathrm{s}} B m$ & 21 & & 0.996 & 19.0 & $9.32 \downarrow$ & $6.38 \downarrow$ & $27.2 \downarrow$ \\
\hline & $\mathrm{Me}$ & & & $<\mathrm{DL}$ & 18.6 & 8.51 & 5.43 & 27.2 \\
\hline & Max & & & 6.885 & 22.8 & 10.93 & 9.04 & 30.8 \\
\hline \multirow{18}{*}{ II } & No $P$ & 0 & \multirow[t]{7}{*}{$\mathrm{PP}-$} & 0.776 & $15.8 \downarrow^{2}$ & $6.17 \downarrow$ & $7.67 \downarrow$ & $43.3 \downarrow$ \\
\hline & $\mathrm{SP}$ & 17.6 & & $<\mathrm{DL}$ & $16.5 \downarrow$ & $6.87 \downarrow$ & $7.10 \downarrow$ & $43.2 \downarrow$ \\
\hline & \multirow{6}{*}{$\mathrm{A}_{\mathrm{s}} B m$} & 26.4 & & $<\mathrm{DL}$ & $15.3 \downarrow$ & $6.54 \downarrow$ & $7.71 \downarrow$ & $42.3 \downarrow$ \\
\hline & & 35.2 & & 2.598 & $15.3 \downarrow$ & $5.37 \downarrow$ & $7.94 \downarrow$ & $42.7 \downarrow$ \\
\hline & & 17.6 & & 3.047 & $15.8 \downarrow$ & $6.47 \downarrow$ & $7.98 \downarrow$ & $42.9 \downarrow$ \\
\hline & & 26.4 & & 0.814 & $15.4 \downarrow$ & $5.80 \downarrow$ & $7.59 \downarrow$ & $42.3 \downarrow$ \\
\hline & & 35.2 & & $<\mathrm{DL}$ & $15.8 \downarrow$ & $5.48 \downarrow$ & $7.94 \downarrow$ & $42.9 \downarrow$ \\
\hline & & average & & 1.248 & $15.7 \downarrow$ & $6.10 \downarrow$ & $7.71 \downarrow$ & $42.8 \downarrow$ \\
\hline & No P & 0 & \multirow[t]{7}{*}{$\mathrm{PP}+$} & $<\mathrm{DL}$ & $15.8 \downarrow$ & $6.51 \downarrow$ & $7.34 \downarrow$ & $43.3 \downarrow$ \\
\hline & SP & 17.6 & & 1.925 & $16.0 \downarrow$ & $5.62 \downarrow$ & $7.57 \downarrow$ & $43.1 \downarrow$ \\
\hline & & 26.4 & & $<\mathrm{DL}$ & $17.4 \downarrow$ & $5.79 \downarrow$ & $7.56 \downarrow$ & $43.5 \downarrow$ \\
\hline & \multirow{5}{*}{$\mathrm{A}_{\mathrm{s}} B m$} & 35.2 & & 3.280 & $16.3 \downarrow$ & $7.37 \downarrow$ & $7.38 \downarrow$ & $42.0 \downarrow$ \\
\hline & & 17.6 & & $<\mathrm{DL}$ & $14.7 \downarrow$ & $6.11 \downarrow$ & $7.59 \downarrow$ & $42.9 \downarrow$ \\
\hline & & 26.4 & & $<\mathrm{DL}$ & $15.3 \downarrow$ & $5.37 \downarrow$ & $7.65 \downarrow$ & $41.8 \downarrow$ \\
\hline & & 35.2 & & $<\mathrm{DL}$ & $16.3 \downarrow$ & $7.82 \downarrow$ & $7.16 \downarrow$ & $42.3 \downarrow$ \\
\hline & & average & & 1.101 & $16.0 \downarrow$ & $6.37 \downarrow$ & $7.46 \downarrow$ & $42.7 \downarrow$ \\
\hline & $\mathrm{Me}$ & & & $<\mathrm{DL}$ & 14.7 & 5.54 & 7.34 & 42.4 \\
\hline & Max & & & 8.841 & 21.5 & 11.0 & 14.8 & 51.5 \\
\hline \multirow{12}{*}{ III } & No P & 0 & \multirow[t]{10}{*}{$\mathrm{PP}+$} & 1.257 & $19.8 \downarrow$ & $7.29 \downarrow$ & 8.77 & $38.0 \downarrow$ \\
\hline & $\mathrm{SP}$ & 17.6 & & 1.428 & $19.7 \downarrow$ & $8.67 \downarrow$ & 5.53 & $40.1 \downarrow$ \\
\hline & & 26.4 & & $<\mathrm{DL}$ & $19.3 \downarrow$ & $8.62 \downarrow$ & 8.43 & $41.9 \downarrow$ \\
\hline & & 35.2 & & $<\mathrm{DL}$ & $19.0 \downarrow$ & $8.34 \downarrow$ & 5.87 & $40.4 \downarrow$ \\
\hline & $\mathrm{A}_{\mathrm{g}} A f$ & 17.6 & & $<\mathrm{DL}$ & $19.2 \downarrow$ & $9.32 \downarrow$ & 7.15 & $40.5 \downarrow$ \\
\hline & & 26.4 & & 1.113 & $19.8 \downarrow$ & $9.26 \downarrow$ & 8.76 & $37.3 \downarrow$ \\
\hline & \multirow{4}{*}{$\mathrm{AB}_{\mathrm{g}} A f$} & 35.2 & & $<\mathrm{DL}$ & $19.3 \downarrow$ & $8.16 \downarrow$ & 6.04 & $39.1 \downarrow$ \\
\hline & & 17.6 & & 0.711 & $19.3 \downarrow$ & $8.23 \downarrow$ & 5.67 & $39.2 \downarrow$ \\
\hline & & 26.4 & & 0.806 & $19.6 \downarrow$ & $7.20 \downarrow$ & 6.24 & $38.7 \downarrow$ \\
\hline & & 35.2 & & 0.705 & $20.0 \downarrow$ & $8.26 \downarrow$ & 8.35 & $38.2 \downarrow$ \\
\hline & $\mathrm{Me}$ & & & $<\mathrm{DL}$ & 19.9 & 7.84 & 7.37 & 38.6 \\
\hline & Max & & & 2.950 & 23.2 & 13.56 & 12.2 & 47.4 \\
\hline \multirow{12}{*}{ IV } & No $P$ & 0 & \multirow[t]{10}{*}{$\mathrm{PP}+$} & 1.319 & $18.7 \downarrow$ & $7.57 \downarrow$ & 9.91 & $37.6 \downarrow$ \\
\hline & $\mathrm{SP}$ & 17.6 & & 1.242 & $20.9 \downarrow$ & $8.13 \downarrow$ & 9.95 & $38.9 \downarrow$ \\
\hline & & 26.4 & & 1.356 & $19.6 \downarrow$ & $7.65 \downarrow$ & 9.40 & $38.1 \downarrow$ \\
\hline & & 35.2 & & 1.286 & $18.1 \downarrow$ & $7.33 \downarrow$ & 9.99 & $38.2 \downarrow$ \\
\hline & $\mathrm{AB}_{\mathrm{g}}$ & 17.6 & & 0.931 & $18.8 \downarrow$ & $7.96 \downarrow$ & 9.67 & $36.5 \downarrow$ \\
\hline & & 26.4 & & 1.154 & $19.7 \downarrow$ & $7.76 \downarrow$ & 10.30 & $37.1 \downarrow$ \\
\hline & & 35.2 & & 1.573 & $20.4 \downarrow$ & $7.99 \downarrow$ & 10.20 & $43.1 \downarrow$ \\
\hline & \multirow[t]{3}{*}{$\mathrm{AB}_{\mathrm{g}} B m$} & 17.6 & & 0.819 & $15.5 \downarrow$ & $7.99 \downarrow$ & 10.39 & $40.5 \downarrow$ \\
\hline & & 26.4 & & 1.513 & $20.5 \downarrow$ & $8.62 \downarrow$ & 10.20 & $37.9 \downarrow$ \\
\hline & & 35.2 & & 1.423 & $19.6 \downarrow$ & $7.75 \downarrow$ & 10.12 & $36.2 \downarrow$ \\
\hline & $\mathrm{Me}$ & & & 0.758 & 19.2 & 7.97 & 10.0 & 37.8 \\
\hline & Max & & & 4.082 & 23.8 & 10.6 & 15.1 & 55.0 \\
\hline
\end{tabular}

${ }^{1} \mathrm{SP}$-superphosphate, $\mathrm{A}_{\mathrm{s}} B m$-SSA-based suspension fertilizer with $B$. megaterium, $\mathrm{B}_{\mathrm{s}} B m$-bone-based suspension fertilizer with $B$. megaterium, $\mathrm{A}_{\mathrm{g}} A f$-SSA-based granular fertilizer with A. ferrooxidans, $\mathrm{AB} \mathrm{B}_{\mathrm{g}} A f-\mathrm{SSA}$-bone-based granular fertilizer with $A$. ferrooxidans, $\mathrm{AB}_{\mathrm{g}}-$ SSA-bone-based granular fertilizer without PSM, $\mathrm{AB}_{\mathrm{g}} B m$-SSA-bone-based granular fertilizer with B. megaterium; ${ }^{2}$ arrows $(\downarrow)$ indicate significant decrease in relation to the starting state; for P-fertilization treatments (Experiments I-IV) and plant protection treatments (Experiment II), there were no significant differences. 
Recycled fertilizers, similar to SP, did not significantly change the soil content of tested PTE as compared to no $\mathrm{P}$ treatments in any of the experiments, regardless of $\mathrm{P}$ dose. The application of $\mathrm{PP}+$ compared to $\mathrm{PP}-$ (Experiment II) also did not change the soil PTE content.

The enrichment of soil PTE under P fertilization was not observed in any of the experiments. Moreover, in comparison with the initial state (before the experiments and fertilization treatments), a significant decrease in soil $\mathrm{Cr}$ content was observed in Experiments II-IV, Ni in Experiments I and II, and $\mathrm{Cu}$ and $\mathrm{Zn}$ in all experiments, but with no relation to the $\mathrm{P}$ fertilization applied. Since $\mathrm{Cu}, \mathrm{Ni}$, and $\mathrm{Zn}$ are micronutrients for plants [6], their depletion in soil was probably caused by plant uptake (wheat and weeds). The higher yields of P-fertilized plants and the resulting greater uptake of elements explain the statistically even decrease in soil PTE under P-treatments and under no P treatments. In particular, $\mathrm{Cu}$ and $\mathrm{Zn}$, being key micronutrients for cereals [89], can be readily taken up by plants if available [90]. Although any biological role of $\mathrm{Cr}$ in plant physiology is known to date [91], it may be taken up along essential elements, such as sulfate through sulfate transporters [92]. In soils with a pH below 6.5, as in the experiments presented here, the solubility of PTE and, thus, their mobility and plant availability are increased [93]. Therefore, leaching and runoff of PTE, even of $\mathrm{Cu}$ and $\mathrm{Zn}$, which are considered hardly leached from the soil, also cannot be excluded [88,94,95]. In none of the experiments was a change in the soil As content, in relation to the initial state, noted. According to Jiao et al. [96], under normal cropping practices, As accumulation in soils is insignificant. Chen et al. [97] reported that more than $90 \%$ of As introduced through fertilizer applications is expected to leach below the root zone over time.

Earlier studies by other authors indicate that feeding plants with fertilizers containing PTE, both from primary or secondary resources, may lead to an increase in their content in soil as a result of a longer-term application $[95,98,99]$, or even during one growing season [98]. In contrast, based on a permanent arable field investigation, Uprety et al. [100] concluded that common cropping practices with the application of organic and inorganic fertilizers do not substantially enrich levels of $\mathrm{As}, \mathrm{Cd}, \mathrm{Cr}, \mathrm{Cu}, \mathrm{Ni}$, and $\mathrm{Pb}$ in soils, even after they have been applied for more than 50 years. Chen et al. [15] found no increase in soil $\mathrm{Cu}, \mathrm{Cr}$, and $\mathrm{Ni}$ content after a 10-year application of $0.016,0.042$, and $0.022 \mathrm{~kg}$ of these elements, respectively, along with $400 \mathrm{~kg} \cdot \mathrm{ha}^{-1} \mathrm{P}$, and no increase in As and $\mathrm{Zn}$ content when applied at rates up to $0.042 \mathrm{~kg}$ (with $200 \mathrm{~kg} \cdot \mathrm{ha}^{-1} \mathrm{P}$ ) and $0.027 \mathrm{~kg}$ (with $100 \mathrm{~kg} \cdot \mathrm{ha}^{-1} \mathrm{P}$ ), respectively. It is worth noting that the amounts of non-essential As introduced into the soil, together with all recycled fertilizers tested in the present study, were substantially lower (compare Table 9). However, considering the role of those PTE as essential micronutrients, particularly of $\mathrm{Cu}$ and $\mathrm{Zn}$, their moderately higher quantities added to the soil along with the recycled fertilizers may be beneficial rather than problematic [90].

\subsection{PTE in Plant Biomass}

\subsubsection{Wheat Grain and Straw}

Wheat grain constitutes the basis of many food products worldwide, so its contamination with PTE is of particular concern [12,101]. The PTE content of straw becomes important if it is used for animal feed [102]. In all the conducted experiments, recycled fertilizers applied at three $\mathrm{P}$ rates showed no effect on the $\mathrm{As}, \mathrm{Cr}, \mathrm{Cu}, \mathrm{Ni}$, and $\mathrm{Zn}$ content in wheat grain or straw (Table 11). Similarly, PTE contents in grain and straw were not differentiated by SP. 
Table 11. PTE content in wheat grain, $\mathrm{mg} \cdot \mathrm{kg}^{-1} \mathrm{DM}(\mathrm{n}=4)$.

\begin{tabular}{|c|c|c|c|c|c|c|c|c|}
\hline Experiment & P-Fertilizer & P-Dose, $\mathrm{kg} \cdot \mathrm{ha}^{-1}$ & Plant Protection & As & $\mathrm{Cr}$ & $\mathrm{Cu}$ & $\mathrm{Ni}$ & $\mathrm{Zn}$ \\
\hline \multirow{6}{*}{ I } & No $P$ & 0 & \multirow[t]{4}{*}{$\mathrm{PP}-$} & $<\mathrm{DL}$ & 0.307 & 2.85 & 0.182 & 22.1 \\
\hline & $\mathrm{SP}^{1}$ & 21 & & $<\mathrm{DL}$ & 0.118 & 2.77 & 0.132 & 21.9 \\
\hline & $\mathrm{A}_{\mathrm{s}} B m$ & 21 & & $<\mathrm{DL}$ & 0.125 & 3.00 & 0.079 & 23.2 \\
\hline & $\mathrm{B}_{\mathrm{S}} B m$ & 21 & & $<\mathrm{DL}$ & 0.223 & 2.74 & 0.034 & 21.5 \\
\hline & $\mathrm{Me}$ & & & $<\mathrm{DL}$ & 0.141 & 2.79 & 0.096 & 22.1 \\
\hline & Max & & & 0.050 & 0.748 & 3.45 & 0.362 & 25.9 \\
\hline \multirow{18}{*}{ II } & No $P$ & 0 & \multirow[t]{7}{*}{$\mathrm{PP}-$} & 0.054 & 0.233 & 3.70 & 0.028 & 40.9 \\
\hline & SP & 17.6 & & 0.059 & $<\mathrm{DL}$ & 3.70 & 0.065 & 42.3 \\
\hline & \multirow{6}{*}{$\mathrm{A}_{\mathrm{s}} B m$} & 26.4 & & $<\mathrm{DL}$ & 0.193 & 3.32 & 0.027 & 39.1 \\
\hline & & 35.2 & & $<\mathrm{DL}$ & 0.196 & 3.55 & 0.086 & 41.2 \\
\hline & & 17.6 & & $<\mathrm{DL}$ & 0.008 & 3.76 & 0.031 & 47.6 \\
\hline & & 26.4 & & $<\mathrm{DL}$ & 0.058 & 3.64 & 0.058 & 39.7 \\
\hline & & 35.2 & & $<\mathrm{DL}$ & 0.084 & 3.87 & 0.033 & 42.8 \\
\hline & & average & & 0.047 & 0.111 & $3.65 b^{2}$ & 0.047 & 41.9 \\
\hline & No P & 0 & \multirow[t]{7}{*}{$\mathrm{PP}+$} & 0.074 & 0.072 & 4.32 & 0.008 & 39.9 \\
\hline & $\mathrm{SP}$ & 17.6 & & $<\mathrm{DL}$ & 0.083 & 3.91 & 0.008 & 37.2 \\
\hline & \multirow{6}{*}{$\mathrm{A}_{\mathrm{s}} B m$} & 26.4 & & $<\mathrm{DL}$ & 0.063 & 4.07 & 0.032 & 40.1 \\
\hline & & 35.2 & & 0.052 & $<\mathrm{DL}$ & 4.01 & 0.068 & 38.7 \\
\hline & & 17.6 & & $<\mathrm{DL}$ & 0.131 & 3.92 & 0.034 & 41.2 \\
\hline & & 26.4 & & $<\mathrm{DL}$ & 0.157 & 3.63 & 0.050 & 37.6 \\
\hline & & 35.2 & & $<\mathrm{DL}$ & 0.018 & 3.58 & 0.016 & 41.3 \\
\hline & & average & & 0.051 & 0.076 & $3.92 \mathrm{a}$ & 0.031 & 39.4 \\
\hline & $\mathrm{Me}$ & & & $<\mathrm{DL}$ & 0.011 & 3.79 & 0.022 & 41.0 \\
\hline & Max & & & 0.125 & 0.521 & 4.67 & 0.235 & 56.4 \\
\hline \multirow{12}{*}{ III } & No $P$ & 0 & \multirow[t]{10}{*}{$\mathrm{PP}+$} & $<\mathrm{DL}$ & 0.033 & 2.31 & 0.179 & 26.4 \\
\hline & $\mathrm{SP}$ & 17.6 & & 0.062 & 0.015 & 2.09 & 0.215 & 25.5 \\
\hline & & 26.4 & & $<\mathrm{DL}$ & $<\mathrm{DL}$ & 2.17 & 0.180 & 24.0 \\
\hline & & 35.2 & & $<\mathrm{DL}$ & 0.159 & 2.09 & 0.245 & 24.2 \\
\hline & $\mathrm{A}_{\mathrm{g}} A f$ & 17.6 & & 0.057 & 0.132 & 2.50 & 0.149 & 24.7 \\
\hline & \multirow{5}{*}{$\mathrm{AB}_{\mathrm{g}} A f$} & 26.4 & & 0.081 & $<\mathrm{DL}$ & 2.39 & 0.187 & 24.2 \\
\hline & & 35.2 & & $<\mathrm{DL}$ & 0.062 & 2.17 & 0.122 & 27.1 \\
\hline & & 17.6 & & 0.063 & 0.112 & 2.39 & 0.287 & 27.5 \\
\hline & & 26.4 & & 0.058 & 0.133 & 2.43 & 0.182 & 24.6 \\
\hline & & 35.2 & & $<\mathrm{DL}$ & 0.165 & 2.36 & 0.230 & 27.2 \\
\hline & $\mathrm{Me}$ & & & $<\mathrm{DL}$ & $<\mathrm{DL}$ & 2.30 & 0.164 & 25.4 \\
\hline & Max & & & 0.173 & 0.630 & 2.93 & 0.691 & 33.2 \\
\hline \multirow{12}{*}{ IV } & No P & 0 & \multirow[t]{10}{*}{$\mathrm{PP}+$} & 0.056 & 0.228 & 3.85 & 0.189 & 26.0 \\
\hline & $\mathrm{SP}$ & 17.6 & & $<\mathrm{DL}$ & 0.068 & 3.74 & 0.113 & 24.1 \\
\hline & & 26.4 & & $<\mathrm{DL}$ & 0.176 & 3.57 & 0.125 & 24.1 \\
\hline & & 35.2 & & $<\mathrm{DL}$ & 0.405 & 3.36 & 0.087 & 22.7 \\
\hline & $\mathrm{AB}_{\mathrm{g}}$ & 17.6 & & $<\mathrm{DL}$ & 0.591 & 4.04 & 0.167 & 24.9 \\
\hline & \multirow{5}{*}{$\mathrm{AB}_{\mathrm{g}} B m$} & 26.4 & & 0.065 & 0.314 & 3.74 & 0.144 & 24.3 \\
\hline & & 35.2 & & $<\mathrm{DL}$ & 0.180 & 3.92 & 0.138 & 25.7 \\
\hline & & 17.6 & & 0.052 & 0.143 & 4.05 & 0.149 & 24.2 \\
\hline & & 26.4 & & $<\mathrm{DL}$ & 0.179 & 3.95 & 0.185 & 25.6 \\
\hline & & 35.2 & & $<\mathrm{DL}$ & 0.247 & 3.90 & 0.250 & 27.0 \\
\hline & $\mathrm{Me}$ & & & $<\mathrm{DL}$ & 0.168 & 3.81 & 0.126 & 24.8 \\
\hline & Max & & & 0.087 & 0.992 & 5.11 & 0.390 & 33.4 \\
\hline
\end{tabular}

${ }^{1} \mathrm{SP}$-superphosphate, $\mathrm{A}_{\mathrm{s}} B m$-SSA-based suspension fertilizer with $B$. megaterium, $\mathrm{B}_{\mathrm{s}} B m$-bone-based suspension fertilizer with $B$. megaterium, $\mathrm{A}_{\mathrm{g}} A f$-SSA-based granular fertilizer with A. ferrooxidans, $\mathrm{AB} A f-S S A$-bone-based granular fertilizer with $A$. ferrooxidans, $\mathrm{AB}_{\mathrm{g}}-$ SSA-bone-based granular fertilizer without PSM, $\mathrm{AB}_{\mathrm{g}} B m$-SSA-bone-based granular fertilizer with B. megaterium; ${ }^{2}$ different letters indicate significant differences at $p<0.05$ for plant protection treatments in Experiment II; for P-fertilization treatments (Experiments I-IV), there were no significant differences. 
In all experiments, $\mathrm{As}, \mathrm{Cr}, \mathrm{Cu}, \mathrm{Ni}$, and $\mathrm{Zn}$ were typically found in wheat grain in amounts considered normal or sufficient and did not reach levels indicative of excessive or toxic content (Table 7). The As content in wheat grain was usually far below the value of $0.2 \mathrm{mg} \cdot \mathrm{kg}^{-1}$. This level was previously defined in Poland as the maximum permissible value for cereal grains for food purposes (the relevant regulation was abolished). Today, FAO/WHO and EU standards limit only the inorganic As content of rice grains for human consumption. The highest As content detected in grain was $0.173 \mathrm{mg} \cdot \mathrm{kg}^{-1}$ (in Experiment III), while median values in all experiments were below the detection level. No standards for $\mathrm{Cr}, \mathrm{Cu}, \mathrm{Ni}$, and $\mathrm{Zn}$ contents in cereal grains have yet been developed in Poland. Moreover, $\mathrm{FAO} / \mathrm{WHO}$ and $\mathrm{EU}$ have also not provided limits for these metals in food grain (Table 7). In China, the consumption of grain is considered safe when $\mathrm{Cr}$ accumulation is under $1 \mathrm{mg} \cdot \mathrm{kg}^{-1}$ [79]. Although Cr contents in grain in the present study did not exceed this level, the highest value $\left(0.992 \mathrm{mg} \cdot \mathrm{kg}^{-1}\right)$ determined in wheat fertilized with $\mathrm{AB}_{\mathrm{g}}$ (Experiment IV) was dangerously close to it. However, in Experiment $\mathrm{I}$, the highest $\mathrm{Cr}$ content in grain $\left(0.748 \mathrm{mg} \cdot \mathrm{kg}^{-1}\right)$ was found under no P treatment. Similarly, Kulczycki and Sacała [103] found an average Cr content of $0.77 \mathrm{mg} \cdot \mathrm{kg}^{-1}$ in wheat grain with no $\mathrm{Cr}$ treatment. The $\mathrm{Cu}, \mathrm{Ni}$, and $\mathrm{Zn}$ contents were within ranges typical for cereal grains and usually did not exceed the maximum values suggested by Kabata-Pendias et al. [80] for plant material to be used for food and feed purposes (Table 7); an exception was the maximum $\mathrm{Zn}$ content in grain in Experiment II $\left(56.4 \mathrm{mg} \cdot \mathrm{kg}^{-1}\right)$. The Cu content in grain in Experiments II and IV was within the range of 3-6 mg $\cdot \mathrm{kg}^{-1}$, defined by Korzeniowska and Kantek [104] as optimal for plants and for grain consumers (humans and animals), while in Experiments I and III, it usually did not exceed the level of $3 \mathrm{mg} \cdot \mathrm{kg}^{-1}$. The $\mathrm{Zn}$ content, in turn, rarely reached or exceeded $45 \mathrm{mg}$, i.e., the target value of wheat grain $\mathrm{Zn}$ biofortification, which is considered optimal to meet the $\mathrm{Zn}$ needs of the human body [105].

The contents of $\mathrm{As}, \mathrm{Cu}, \mathrm{Ni}$, and $\mathrm{Zn}$ in wheat straw in all experiments (Table 12) were normal or sufficient (Table 7). The $\mathrm{Cr}$ content in wheat straw was elevated, especially in Experiments II and IV, and the maximum value obtained in Experiment II $\left(5.97 \mathrm{mg} \cdot \mathrm{kg}^{-1}\right)$ even fell within the range considered excessive or toxic for plants. However, none of the values exceeded the permissible or suggested limits for a feed use plant material and no symptoms of $\mathrm{Cr}$ toxicity [92] were observed in wheat plants.

In each experiment, the content of $\mathrm{As}, \mathrm{Cr}$, and $\mathrm{Ni}$ in straw was noticeably higher than in grain, which is consistent with the common opinion that the pattern of accumulation of these PTE in the various parts of the plant is: roots > stem > leaves > seed/grain [106,107]. The relatively higher As content in winter wheat straw (Experiments III and IV) than in spring wheat straw (Experiments I and II) is explained by differences across the cultivars in PTE accumulation and translocation to different plant parts [108]. The noticeably higher $\mathrm{Cr}$ content in wheat straw in Experiments II and IV was probably due to the increased $\mathrm{Cr}$ solubility and availability in soil $\mathrm{pH}<5.5$ [4].

The level of $\mathrm{Cu}$ in wheat straw and grain was similar in three of the four experiments conducted, and only in Experiment III was a noticeably greater amount of $\mathrm{Cu}$ accumulated in straw than in grain. In the available literature, different patterns for the $\mathrm{Cu}$ accumulation in wheat grain and straw were reported: grain $\mathrm{Cu}>$ straw $\mathrm{Cu}$ [109], grain $\mathrm{Cu} \approx$ straw $\mathrm{Cu}$ [110], grain $\mathrm{Cu}<$ straw $\mathrm{Cu}$ [107]. Based on existing knowledge, the $\mathrm{Cu}$ amount loaded into wheat grain depends on both the $\mathrm{Cu}$ amount taken up by the plant post-anthesis and the amount that is remobilized (quite readily) from vegetative organs as they senesce [111]. According to Hill et al. [112], the Cu retranslocation from vegetation to grain may be limited due to $\mathrm{Cu}$ retention by senesced vegetation at marginal $\mathrm{Cu}$ content, and large numbers of tillers produced by wheat may have competed with the developing grain for retranslocated $\mathrm{Cu}$. It seems that the latter is the best explanation for the described result from Experiment III, since the tillering coefficients for wheat in this experiment were the highest [113]. 
Table 12. PTE content in wheat straw, $\mathrm{mg} \cdot \mathrm{kg}^{-1} \mathrm{DM}(\mathrm{n}=4)$.

\begin{tabular}{|c|c|c|c|c|c|c|c|c|}
\hline Experiment & P-Fertilizer & P-Dose, $\mathrm{kg} \cdot \mathrm{ha}^{-1}$ & Plant Protection & As & $\mathrm{Cr}$ & $\mathrm{Cu}$ & $\mathrm{Ni}$ & Zn \\
\hline \multirow{6}{*}{ I } & No $P$ & 0 & \multirow[t]{4}{*}{$\mathrm{PP}-$} & 0.277 & 0.327 & 2.55 & 0.321 & 5.18 \\
\hline & $\mathrm{SP}^{1}$ & 21 & & 0.127 & 0.288 & 2.54 & 0.292 & 2.83 \\
\hline & $\mathrm{A}_{\mathrm{s}} B m$ & 21 & & 0.250 & 0.311 & 2.61 & 0.245 & 3.27 \\
\hline & $\mathrm{B}_{\mathrm{S}} B m$ & 21 & & 0.381 & 0.486 & 2.71 & 0.344 & 3.75 \\
\hline & $\mathrm{Me}$ & & & 0.249 & 0.358 & 2.63 & 0.299 & 1.41 \\
\hline & Max & & & 0.578 & 0.988 & 3.07 & 0.496 & 10.83 \\
\hline \multirow{18}{*}{ II } & No $P$ & 0 & \multirow[t]{7}{*}{$\mathrm{PP}-$} & 0.171 & 2.99 & 3.36 & 0.421 & 18.52 \\
\hline & SP & 17.6 & & 0.050 & 1.95 & 3.51 & 0.458 & 14.01 \\
\hline & \multirow{6}{*}{$\mathrm{A}_{\mathrm{s}} B m$} & 26.4 & & 0.156 & 3.18 & 3.78 & 0.535 & 13.69 \\
\hline & & 35.2 & & 0.073 & 3.46 & 3.53 & 0.576 & 14.51 \\
\hline & & 17.6 & & 0.081 & 2.49 & 3.43 & 0.454 & 13.30 \\
\hline & & 26.4 & & 0.106 & 1.98 & 3.49 & 0.337 & 14.22 \\
\hline & & 35.2 & & 0.076 & 2.06 & 3.66 & 0.352 & 13.73 \\
\hline & & average & & 0.102 & 2.59 & 3.54 & 0.447 & $14.57 \mathrm{a}^{2}$ \\
\hline & No $P$ & 0 & \multirow[t]{7}{*}{$\mathrm{PP}+$} & 0.084 & 3.08 & 3.63 & 0.339 & 10.44 \\
\hline & $\mathrm{SP}$ & 17.6 & & 0.085 & 3.66 & 4.68 & 0.606 & 9.20 \\
\hline & \multirow{6}{*}{$\mathrm{A}_{\mathrm{s}} B m$} & 26.4 & & 0.121 & 2.05 & 4.01 & 0.307 & 9.41 \\
\hline & & 35.2 & & 0.069 & 2.16 & 3.76 & 0.263 & 8.30 \\
\hline & & 17.6 & & 0.112 & 3.58 & 3.69 & 0.692 & 9.35 \\
\hline & & 26.4 & & 0.067 & 1.57 & 3.10 & 0.133 & 8.78 \\
\hline & & 35.2 & & 0.050 & 2.24 & 4.47 & 0.396 & 9.84 \\
\hline & & average & & 0.084 & 2.62 & 3.90 & 0.391 & $9.33 \mathrm{~b}$ \\
\hline & $\mathrm{Me}$ & & & 0.050 & 1.98 & 3.67 & 0.409 & 11.12 \\
\hline & Max & & & 0.474 & 5.97 & 5.76 & 1.420 & 24.95 \\
\hline \multirow{12}{*}{ III } & No $P$ & 0 & \multirow[t]{10}{*}{$\mathrm{PP}+$} & 0.516 & 0.415 & 6.43 & 0.530 & 6.16 \\
\hline & $\mathrm{SP}$ & 17.6 & & 0.393 & 0.493 & 6.13 & 0.710 & 6.78 \\
\hline & & 26.4 & & 0.373 & 0.484 & 6.11 & 0.284 & 6.41 \\
\hline & & 35.2 & & 0.556 & 0.385 & 6.06 & 0.440 & 5.98 \\
\hline & $\mathrm{A}_{\mathrm{g}} A f$ & 17.6 & & 0.343 & 0.315 & 5.83 & 0.277 & 5.98 \\
\hline & \multirow{5}{*}{$\mathrm{AB}_{\mathrm{g}} A f$} & 26.4 & & 0.582 & 0.531 & 6.37 & 0.221 & 6.28 \\
\hline & & 35.2 & & 0.458 & 0.492 & 4.08 & 0.236 & 6.20 \\
\hline & & 17.6 & & 0.515 & 0.430 & 7.02 & 0.248 & 5.84 \\
\hline & & 26.4 & & 0.465 & 0.690 & 6.20 & 0.384 & 5.75 \\
\hline & & 35.2 & & 0.415 & 0.599 & 6.08 & 0.558 & 6.12 \\
\hline & $\mathrm{Me}$ & & & 0.426 & 0.450 & 6.17 & 0.284 & 6.29 \\
\hline & Max & & & 0.961 & 1.546 & 9.26 & 1.492 & 8.23 \\
\hline \multirow{12}{*}{ IV } & No P & 0 & \multirow[t]{10}{*}{$\mathrm{PP}+$} & 0.453 & 0.99 & 4.12 & 0.234 & 7.36 \\
\hline & $\mathrm{SP}$ & 17.6 & & 0.643 & 0.71 & 6.34 & 0.310 & 7.54 \\
\hline & & 26.4 & & 0.738 & 1.11 & 5.00 & 0.235 & 6.79 \\
\hline & & 35.2 & & 0.448 & 1.03 & 5.39 & 0.256 & 6.82 \\
\hline & $\mathrm{AB}_{\mathrm{g}}$ & 17.6 & & 0.505 & 0.79 & 5.96 & 0.503 & 7.25 \\
\hline & & 26.4 & & 0.475 & 1.29 & 5.04 & 0.296 & 6.17 \\
\hline & & 35.2 & & 0.611 & 0.91 & 3.85 & 0.230 & 7.81 \\
\hline & \multirow[t]{3}{*}{$\mathrm{AB}_{\mathrm{g}} B m$} & 17.6 & & 0.609 & 0.40 & 5.76 & 0.304 & 7.50 \\
\hline & & 26.4 & & 0.786 & 1.25 & 5.72 & 0.288 & 8.34 \\
\hline & & 35.2 & & 0.786 & 0.94 & 4.54 & 0.402 & 8.64 \\
\hline & $\mathrm{Me}$ & & & 0.530 & 0.861 & 4.66 & 0.221 & 7.01 \\
\hline & Max & & & 1.561 & 2.651 & 8.97 & 0.896 & 12.48 \\
\hline
\end{tabular}

${ }^{1} \mathrm{SP}$-superphosphate, $\mathrm{A}_{\mathrm{s}} B m$-SSA-based suspension fertilizer with $B$. megaterium, $\mathrm{B}_{\mathrm{s}} B m$-bone-based suspension fertilizer with $B$. megaterium, $\mathrm{A}_{\mathrm{g}} A f$-SSA-based granular fertilizer with A. ferrooxidans, $\mathrm{AB}_{\mathrm{g}} A f-S S A$-bone-based granular fertilizer with $A$. ferrooxidans, $\mathrm{AB}_{\mathrm{g}}-$ SSA-bone-based granular fertilizer without PSM, $\mathrm{AB}_{\mathrm{g}} B m$-SSA-bone-based granular fertilizer with B. megaterium; ${ }^{2}$ different letters indicate significant differences at $p<0.05$ for plant protection treatments in Experiment II; no letters-no significant differences for plant protection treatments or for P-fertilization treatments. 
The $\mathrm{Zn}$ content in wheat straw was considerably lower than in wheat grain in all experiments. A similar relationship between straw Zn content and grain Zn content was shown by Al-Othman et al. [107]. Although Zn translocation from root to shoot following Zn uptake by the root is affected by many factors [114], it seems that adequate N supply was the reason for the greatest $\mathrm{Zn}$ accumulation in wheat grain in all fields in the present study, as suggested by other authors $[115,116]$. The particularly low straw Zn content in Experiment I was probably related to the low $\mathrm{Zn}$ abundance in the soil (Table 6).

The use of fertilizers containing PTE, both from primary and secondary raw materials, has been associated with concerns about the accumulation of these elements in edible plant parts, including cereal grain $[99,117,118]$. In the present study, the main raw material for recycled fertilizers was SSA. Although direct use of unprocessed SSA in agriculture is legally limited $[119,120]$, it is recommended to produce fertilizers based on new SSA processing technologies that result in concentrated and pure fertilizer products $[43,121]$. To date, however, there are still few studies on SSA and SSA-based fertilizers in the context of their effect on PTE accumulation in usable/consumable plant parts [118,122,123].

Reports from pot experiments provide evidence that SSA originating from the ' $€ y n a$ ' wastewater treatment plant, Olsztyn, used as P-fertilizer did not lead to a significant increase in PTE (Fe, Mn, Zn, Cu, Cd, Pb, Ni, Cr) concentrations in green forage maize [123] and only very slightly modified the PTE content $(\mathrm{Cd}, \mathrm{Cr}, \mathrm{Cu}, \mathrm{Ni}, \mathrm{Mn}, \mathrm{Zn})$ in the Virginia fanpetals plants [122]. Field studies by Iżewska and Wołoszyk [118] demonstrated that the application of SSA (from Pomorzany Sewage Treatment Plant in Szczecin) at rising P doses caused an increase in the content of $\mathrm{Cd}, \mathrm{Ni}$, and $\mathrm{Pb}$ in maize grain, $\mathrm{Cd}$ and $\mathrm{Ni}$ in maize straw, $\mathrm{Cd}$ and $\mathrm{Pb}$ in spring rape seeds, and $\mathrm{Cd}$ in rape straw. In the authors' previous paper, it was reported that SSA-based biofertilizers applied at reasonable amounts in field conditions did not increase the $\mathrm{Cd}$ and $\mathrm{Pb}$ content in wheat grain [60].

Many other studies have been published in which the secondary sources of nutrients did not contribute to increasing the PTE content of the crop plant grown in soil amended in this manner [124-127]. There are also opinions that the levels of elements such as $\mathrm{Cu}$ and Zn normally found in waste-based soil amendments may be beneficial rather than toxic to crop plants [90]. However, considering the chemical heterogeneity of secondary nutrient sources [43] and the complexity of the fertilizer/nutrient source-soil-plant system functioning [128], using them with caution is advisable until long-term studies have verified their full utility and safety.

Plant protection against agrophages (Experiment II) increased $\mathrm{Cu}$ content in wheat grain and decreased $\mathrm{Zn}$ content in wheat straw. The former effect is explained by the reduction in weed competition for $\mathrm{Cu}$ [129], and the latter by a 'dilution effect' [130] of Zn in wheat straw with considerably higher yields under PP+ than under PP - treatments (unpublished data). However, in higher grain yield under $\mathrm{PP}+$, the $\mathrm{Zn}$ dilution was not statistically confirmed. No effect of plant protection on $\mathrm{As}, \mathrm{Cr}, \mathrm{Ni}$, and $\mathrm{Zn}$ content in grain or on $\mathrm{As}, \mathrm{Cr}, \mathrm{Cu}$, and $\mathrm{Ni}$ content in straw was proven. In comparison, Wołejko et al. [131,132] found higher $\mathrm{Cu}$ and $\mathrm{Cr}$ contents in grain and plants when wheat fertilized with granular sludge was protected with herbicide and fungicides in relation to the control treatment, while no differences were found in $\mathrm{Cd}, \mathrm{Ni}, \mathrm{Pb}$, and $\mathrm{Zn}$ contents.

\subsubsection{Weeds}

Weeds compete with crops for nutrients [132], but by depleting PTE content in the shared rhizosphere, they may protect crops from excessive PTE uptake as well [133]. However, in some cases, accumulator weeds can enhance PTE uptake by neighboring crop plants [134] and alter PTE allocation in the different organs of crop plants (i.e., phytoenrichment). This phenomenon may be a potentially serious problem if it leads to an increase in the PTE accumulation in the edible parts of crop plants [133].

The As, $\mathrm{Cr}, \mathrm{Cu}, \mathrm{Ni}$, and $\mathrm{Zn}$ contents determined in the weed biomass in the present study (Table 13) fell within the biological plant variability ranges (Table 7). Although none of the experiments conducted demonstrated any significant effect of the applied P- 
fertilizer treatments on these PTE content in the weed biomass (Table 13), plant protection differentiated the content of $\mathrm{As}, \mathrm{Cr}, \mathrm{Ni}$, and $\mathrm{Zn}$ in Experiment II.

Table 13. PTE content in weeds, $\mathrm{mg} \cdot \mathrm{kg}^{-1} \mathrm{DM}(\mathrm{n}=4)$.

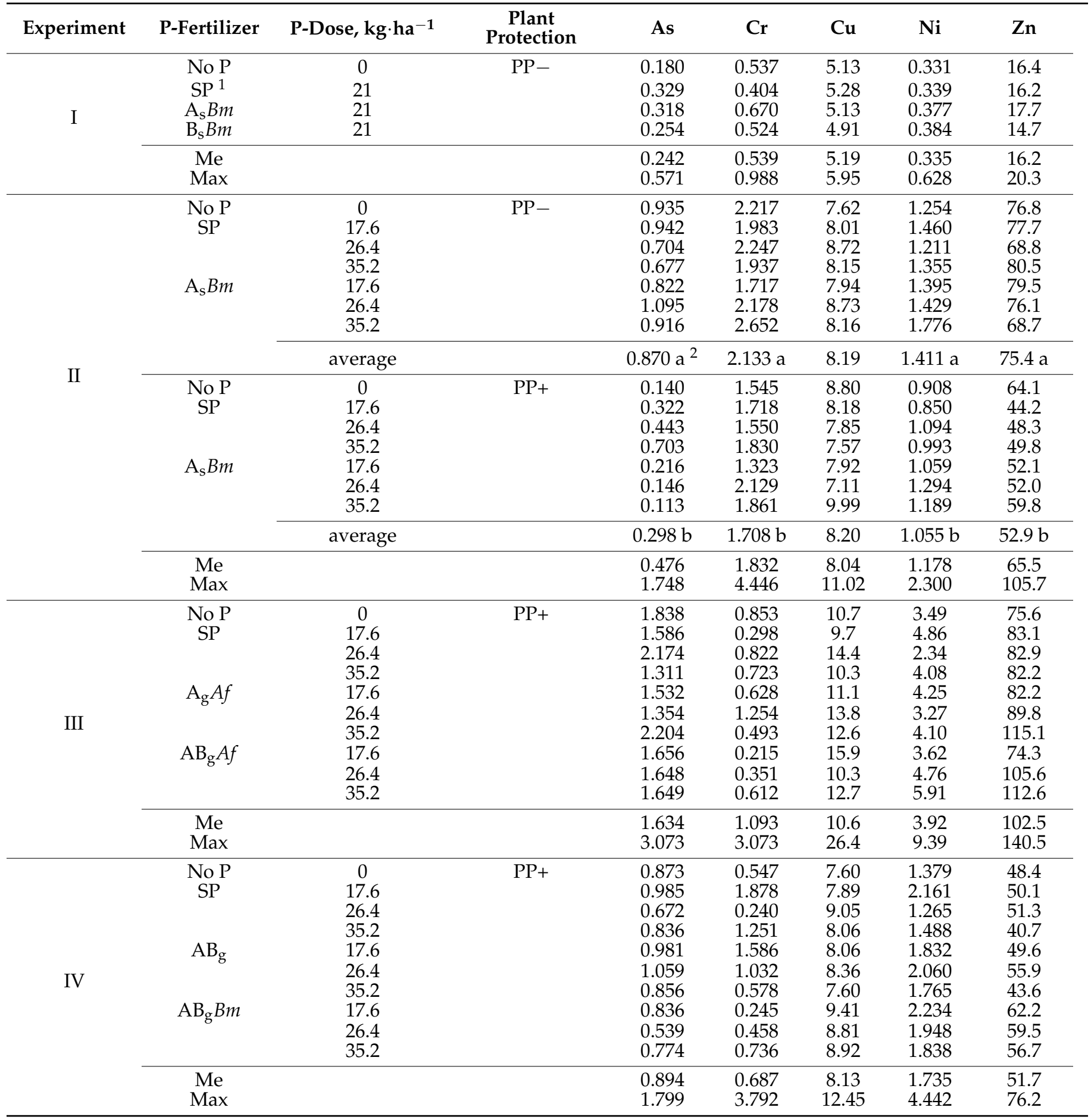

${ }^{1} \mathrm{SP}$ - superphosphate, $\mathrm{A}_{\mathrm{S}} B m$-SSA-based suspension fertilizer with $B$. megaterium, $\mathrm{B}_{\mathrm{s}} B m$ - bone-based suspension fertilizer with $B$. megaterium, $\mathrm{A}_{\mathrm{g}} A f$-SSA-based granular fertilizer with $A$. ferrooxidans, $\mathrm{AB}_{\mathrm{g}} A f$-SSA-bone-based granular fertilizer with $A$. ferrooxidans, $\mathrm{AB}_{\mathrm{g}}-$ SSA-bone-based granular fertilizer without PSM, $\mathrm{AB}_{\mathrm{g}} \mathrm{Bm}$-SSA-bone-based granular fertilizer with $B$. megaterium; ${ }^{2}$ different letters indicate significant differences at $p<0.05$ for plant protection treatments in Experiment II; no letters-no significant differences for plant protection treatments or for P-fertilization treatments.

The variability of PTE content in weed biomass within a single experiment and between experiments resulted from the species composition and structure of weed com- 
munities, along with differentiation related to weed developmental stages, competitive ability, and susceptibility to the herbicide applied. Weed biomass from the wheat field under PP - conditions was dominated by Chenopodium album, Fallopia convolvulus, and Raphanus raphanistrum (unpublished data), which are known to accumulate large amounts of As, Cr, Ni, and Zn [135-139]. The reduction in the share of these species in the community due to the herbicide use ( $\mathrm{PP}+$ ) contributed to a decrease in the content of the aforementioned PTE in the overall biomass of weeds and was manifested by a significant difference in relation to weed biomass under $\mathrm{PP}-$. Relatively high $\mathrm{Cu}, \mathrm{Ni}$, and $\mathrm{Zn}$ contents in weed biomass were found in Experiment III. The weed community in this experiment was dominated by Viola arvensis, which proved to be quite resistant to the applied herbicide. Violaceae are generally considered highly tolerant to heavy metals [140], and the considerable ability of Viola arvensis to accumulate $\mathrm{Cu}, \mathrm{Ni}$, and particularly $\mathrm{Zn}$, was also reported by other authors $[135,136,141]$.

In the present experiments, the PTE contents in weed biomass often exceeded their content in wheat grain and straw. This can have both positive (protection against excessive PTE uptake by the crop) [133] and negative aspects (depriving the crop of a valuable nutrient if the given toxic element is a micronutrient in deficiency) [142].

Although PTE accumulation by weeds and the role of weeds in the phytoremediation of PTE-contaminated habitats has been frequently emphasized in the literature [138,143-145]; however, to date, weeds have not been studied for uptake and accumulation of PTE from recycled fertilizers applied to field crops. Galal and Shehata [146] reported from their experiment with rice irrigated with water canals receiving wastewater discharges that weeds, apart from limiting the growth and production of rice crops by accumulating large amounts of nutrients, had captured heavy metals from the soil and thus improved the quality of rice grains. However, Zubkova et al. [139] claim that the contribution of weeds to the general elimination of trace elements and heavy metals by plants of agrophytocenoses is insignificant.

Since the ecological/ecosystemic functions of weeds, including their contribution to the balance of organic matter, nutrient, and toxic element cycling in the agroecosystem, have begun to be appreciated, the need for research in this area has not weakened $[146,147]$.

\subsubsection{Post-Harvest Residues}

PTE captured and stored in crop roots as well as in the straw (stubble) and weed parts remaining in the field after harvesting are temporarily immobilized in this biomass, avoiding potential rapid leaching into groundwater and water ecosystems [5]. They can then be, however, slowly released and used by succeeding plants [148,149].

In the present study, the PTE contents in post-harvest residues in the individual experiments (Table 14) were determined by the proportion between the biomass of the roots, stubble, and weeds. In addition, weed species composition, weed relative height in the wheat canopy, and the elemental content of those weed parts (roots, stems, or leaves) that predominated in the biomass left in the field, also mattered [150].

In all the conducted experiments, the content of $\mathrm{As}, \mathrm{Cu}, \mathrm{Ni}$, and $\mathrm{Zn}$ in crop residues can be considered natural (Table 7), except for a slightly elevated maximum Ni value in Experiment IV and a particularly low Zn level in Experiment I, which were most likely due to the soil background (Table 6). The $\mathrm{Cr}$ content of crop residue biomass in all experiments fell already within the range of values classified as excessive or toxic; however, this could not be related to the P-fertilizers used, including recycled ones, as the same $\mathrm{Cr}$ level was also recorded under no $\mathrm{P}$ treatments. The P-fertilizer treatments did not differentiate the content of the tested PTE in post-harvest residues in any of the experiments conducted (Table 14). 
Table 14. PTE content in post-harvest residues, $\mathrm{mg} \cdot \mathrm{kg}^{-1} \mathrm{DM}(\mathrm{n}=4)$.

\begin{tabular}{|c|c|c|c|c|c|c|c|c|}
\hline Experiment & P-Fertilizer & P-Dose, $\mathrm{kg} \cdot \mathrm{ha}^{-1}$ & Plant Protection & As & $\mathrm{Cr}$ & $\mathrm{Cu}$ & $\mathbf{N i}$ & $\mathrm{Zn}$ \\
\hline \multirow{6}{*}{ I } & No P & 0 & \multirow{4}{*}{$\mathrm{PP}-$} & 0.577 & 5.64 & 3.52 & 2.08 & 7.79 \\
\hline & $\mathrm{SP}^{1}$ & 21 & & 0.627 & 5.75 & 3.90 & 2.26 & 9.61 \\
\hline & $\mathrm{A}_{\mathrm{S}} B m$ & 21 & & 0.598 & 6.28 & 4.04 & 2.49 & 9.82 \\
\hline & $\mathrm{B}_{\mathrm{s}} B m$ & 21 & & 0.408 & 5.96 & 4.27 & 2.53 & 8.91 \\
\hline & $\mathrm{Me}$ & & & 0.541 & 5.92 & 3.87 & 2.31 & 9.17 \\
\hline & Max & & & 0.778 & 7.06 & 5.10 & 2.92 & 11.71 \\
\hline \multirow{18}{*}{ II } & No P & 0 & \multirow[t]{7}{*}{$\mathrm{PP}-$} & 0.438 & 7.97 & 4.17 & 2.24 & 26.0 \\
\hline & $\mathrm{SP}$ & 17.6 & & 0.369 & 6.46 & 4.79 & 1.94 & 19.5 \\
\hline & \multirow{6}{*}{$\mathrm{A}_{\mathrm{s}} B m$} & 26.4 & & 0.603 & 8.64 & 4.59 & 2.26 & 19.7 \\
\hline & & 35.2 & & 0.385 & 8.50 & 4.95 & 2.29 & 20.6 \\
\hline & & 17.6 & & 0.392 & 8.58 & 4.57 & 2.21 & 21.2 \\
\hline & & 26.4 & & 0.487 & 8.88 & 4.11 & 2.49 & 25.2 \\
\hline & & 35.2 & & 0.548 & 7.23 & 4.41 & 2.31 & 19.9 \\
\hline & & average & & $0.460 \mathrm{a}^{2}$ & 8.04 & $4.51 \mathrm{~b}$ & 2.25 & 21.7 \\
\hline & No P & 0 & \multirow[t]{7}{*}{$\mathrm{PP}+$} & 0.372 & 10.83 & 4.67 & 1.88 & 24.0 \\
\hline & SP & 17.6 & & 0.318 & 11.35 & 5.64 & 1.95 & 21.9 \\
\hline & \multirow{6}{*}{$\mathrm{A}_{\mathrm{s}} B m$} & 26.4 & & 0.245 & 7.92 & 6.01 & 1.87 & 20.9 \\
\hline & & 35.2 & & 0.369 & 9.10 & 5.03 & 2.12 & 25.0 \\
\hline & & 17.6 & & 0.320 & 7.16 & 4.82 & 2.84 & 22.0 \\
\hline & & 26.4 & & 0.309 & 9.05 & 5.90 & 1.74 & 19.0 \\
\hline & & 35.2 & & 0.395 & 8.13 & 4.81 & 2.32 & 23.3 \\
\hline & & average & & $0.332 \mathrm{~b}$ & 9.08 & $5.27 \mathrm{a}$ & 2.10 & 22.3 \\
\hline & $\mathrm{Me}$ & & & 0.375 & 8.32 & 4.84 & 2.04 & 21.9 \\
\hline & Max & & & 0.873 & 16.78 & 8.04 & 4.07 & 34.2 \\
\hline \multirow{12}{*}{ III } & No P & 0 & \multirow[t]{10}{*}{$\mathrm{PP}+$} & 0.634 & 8.92 & 5.33 & 2.73 & 23.5 \\
\hline & $\mathrm{SP}$ & 17.6 & & 0.355 & 9.13 & 5.41 & 2.31 & 22.8 \\
\hline & & 26.4 & & 0.333 & 9.81 & 5.63 & 2.74 & 20.8 \\
\hline & & 35.2 & & 0.232 & 9.78 & 5.59 & 2.60 & 24.3 \\
\hline & $\mathrm{A}_{\mathrm{g}} A f$ & 17.6 & & 0.452 & 10.35 & 6.10 & 3.12 & 29.5 \\
\hline & & 26.4 & & 0.247 & 10.93 & 5.38 & 3.10 & 24.1 \\
\hline & & 35.2 & & 0.407 & 9.80 & 5.27 & 2.68 & 23.0 \\
\hline & \multirow[t]{3}{*}{$\mathrm{AB}_{\mathrm{g}} A f$} & 17.6 & & 0.361 & 8.80 & 5.34 & 2.19 & 22.8 \\
\hline & & 26.4 & & 0.080 & 10.05 & 5.63 & 2.53 & 24.5 \\
\hline & & 35.2 & & 0.209 & 8.51 & 5.74 & 2.77 & 25.7 \\
\hline & $\mathrm{Me}$ & & & 0.227 & 9.75 & 5.32 & 2.51 & 24.3 \\
\hline & Max & & & 1.074 & 13.40 & 8.76 & 4.24 & 34.3 \\
\hline \multirow{12}{*}{ IV } & No $P$ & 0 & \multirow{10}{*}{$\mathrm{PP}+$} & 0.425 & 6.98 & 4.86 & 4.48 & 20.5 \\
\hline & $\mathrm{SP}$ & 17.6 & & 0.734 & 8.78 & 4.85 & 7.26 & 21.9 \\
\hline & & 26.4 & & 0.674 & 8.80 & 5.19 & 6.72 & 22.0 \\
\hline & & 35.2 & & 0.379 & 7.81 & 4.48 & 5.28 & 20.0 \\
\hline & $\mathrm{AB}_{\mathrm{g}}$ & 17.6 & & 0.685 & 9.25 & 4.56 & 6.36 & 22.5 \\
\hline & & 26.4 & & 0.695 & 7.43 & 4.13 & 6.46 & 21.3 \\
\hline & & 35.2 & & 0.398 & 6.84 & 4.19 & 5.02 & 20.6 \\
\hline & \multirow[t]{3}{*}{$\mathrm{AB}_{\mathrm{g}} B m$} & 17.6 & & 0.607 & 7.34 & 4.58 & 5.94 & 19.8 \\
\hline & & 26.4 & & 0.975 & 9.82 & 5.12 & 7.86 & 22.0 \\
\hline & & 35.2 & & 0.779 & 8.02 & 5.56 & 6.56 & 24.2 \\
\hline & $\mathrm{Me}$ & & & 0.652 & 7.757 & 4.61 & 6.32 & 21.4 \\
\hline & Max & & & 1.801 & 15.297 & 7.19 & 11.54 & 29.7 \\
\hline
\end{tabular}

${ }^{1} \mathrm{SP}$-superphosphate, $\mathrm{A}_{\mathrm{s}} B m$-SSA-based suspension fertilizer with $B$. megaterium, $\mathrm{B}_{\mathrm{s}} B m$-bone-based suspension fertilizer with $B$. megaterium, $\mathrm{A}_{\mathrm{g}} A f$-SSA-based granular fertilizer with A. ferrooxidans, $\mathrm{AB}_{\mathrm{g}} A f-S S A$-bone-based granular fertilizer with $A$. ferrooxidans, $\mathrm{AB}_{\mathrm{g}}-$

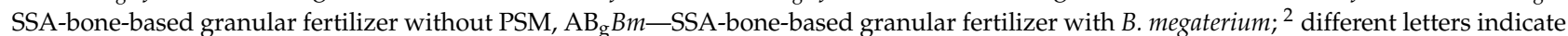
significant differences at $p<0.05$ for plant protection treatments in Experiment II; no letters-no significant differences for plant protection treatments or for P-fertilization treatments. 
Previous studies have shown that roots of crops cultivated in agricultural soil tend to accumulate greater amounts of PTE than the above-ground parts, acting as a barrier to their translocation and protecting edible parts from PTE contamination [107,151,152]. For $\mathrm{Cr}$, it has been reported that plant roots can accumulate up to 100-fold higher amounts of this element than shoots [92]. The very low $\mathrm{Zn}$ content of crop residues in Experiment I suggests a deficit of available $\mathrm{Zn}$ in the soil, along with the relatively lowest initial content of total soil Zn (Table 6), under which wheat plants first stored needed Zn amounts in the grain [153].

In Experiment II, post-harvest residues showed a lower content of As and higher of $\mathrm{Cu}$ under $\mathrm{PP}+$ than under $\mathrm{PP}-$. The lower As content in residue biomass under $\mathrm{PP}+$ is explained by the reduction/elimination from weed communities of those weed species that accumulate more As in their tissues (see Section 3.3.2). In turn, since no difference in $\mathrm{Cu}$ content in weed biomass under PP+ and PP- was found (see Table 13), the higher $\mathrm{Cu}$ content in post-harvest residues under $\mathrm{PP}+$ likely resulted from an increase in the proportion of wheat roots in the residue biomass, which usually contain more $\mathrm{Cu}$ than wheat stems [107,152].

No other studies were found on the effect of recycled fertilizers on $\mathrm{As}, \mathrm{Cr}, \mathrm{Cu}$, Ni, and $\mathrm{Zn}$ contents in post-harvest residues, although a previous paper by the authors found that biofertilizers from renewable raw materials, with low contents of $\mathrm{Cd}$ and $\mathrm{Pb}$, did not alter the PTE contents in post-harvest residues of wheat fields [60]. Partial reference may be provided by studies involving PTE content in wheat straw (see Section 3.3.1), weeds (see Section 3.3.2), and roots, i.e., those plant organs whose parts (remnants) are left in fields after harvest. However, these studies are also scarce.

Considering the retention of PTE in crop residues [149], as well as their carryover between crop rotations [154], more field experiments in this matter are needed.

\section{Conclusions}

The recycled fertilizers tested did not increase the $\mathrm{As}, \mathrm{Cr}, \mathrm{Ni}, \mathrm{Cu}$, and $\mathrm{Zn}$ contents of the soil and plant biomass when applied in amounts up to $35.2 \mathrm{~kg} \cdot \mathrm{P} \cdot \mathrm{ha}^{-1}$. The contents of these elements in soil were below the permissible levels for arable land in Poland. Their concentrations in wheat grain and straw did not exceed the permissible or suggested limits for plant material to be used for food and feed, while in the weed and post-harvest residue biomass, they usually fell within the biological plant variability ranges. Such findings may be one of the first steps toward recommending the presented recycled formulations to replace or supplement traditional commercial fertilizers from primary raw materials. However, considering the potential for PTE accumulation in (and leaching from) the soil, further long-term field studies on PTE fate with repeated applications of recycled fertilizers are needed.

Author Contributions: Conceptualization, M.J., M.K.K. and A.S.; methodology, M.J., M.K.K. and A.S.; validation, M.J., M.K.K., A.S. and W.P.J.; formal analysis, M.J.; investigation, M.J., M.K.K., W.P.J. and A.S.; resources, M.J., M.K.K. and A.S.; writing—original draft preparation, M.J.; writing—review and editing, M.K.K., W.P.J. and A.S.; visualization, M.J.; funding acquisition, A.S, M.J. and M.K.K. All authors have read and agreed to the published version of the manuscript.

Funding: This research was funded by National Center for Research and Development, Poland, grant number PBS 2/A1/11/2013. The APC was funded by the University of Warmia and Mazury in Olsztyn, Faculty of Agriculture and Forestry, Department of Agroecosystems and Horticulture (grant No. 30.610.015-110).

Institutional Review Board Statement: Not applicable.

Informed Consent Statement: Not applicable.

Data Availability Statement: Not applicable.

Acknowledgments: The Institute of New Chemical Synthesis in Puławy is highly acknowledged for providing fertilizers' batches for field experiments. The authors kindly acknowledge the technical 
support of Kinga Treder and Przemysław Makowski from the University of Warmia and Mazury in Olsztyn.

Conflicts of Interest: The authors declare no conflict of interest.

\section{References}

1. Kopittke, P.M.; Menzies, N.W.; Wang, P.; McKenna, B.A.; Lombi, E. Soil and the intensification of agriculture for global food security. Environ. Int. 2019, 132, 105078. [CrossRef] [PubMed]

2. Ganguly, R.K.; Mukherjee, A.; Chakraborty, S.K.; Verma, J.P. Impact of agrochemical application in sustainable agriculture. In New and Future Developments in Microbial Biotechnology and Bioengineering; Verma, J.P., Macdonald, C.A., Gupta, V.K., Podile, A.R., Eds.; Elsevier: Amsterdam, The Netherlands; Oxford, UK; Cambridge, MA, USA, 2021; pp. 15-24.

3. Alengebawy, A.; Abdelkhalek, S.T.; Qureshi, S.R.; Wang, M.-Q. Heavy Metals and pesticides toxicity in agricultural soil and plants: Ecological risks and human health implications. Toxics 2021, 9, 42. [CrossRef] [PubMed]

4. Kabata-Pendias, A. Trace Elements in Soils and Plants, 4th ed.; CRC Press: Boca Raton, FL, USA, 2010; pp. 1-520.

5. Radziemska, M.; Bęś, A.; Gusiatin, Z.M.; Majewski, G.; Mazur, Z.; Bilgin, A.; Jaskulska, I.; Brtnický, M. Immobilization of potentially toxic elements (PTE) by mineral-based amendments: Remediation of contaminated soils in post-industrial sites. Minerals 2020, 10, 87. [CrossRef]

6. Marschner, P. Marschner's Mineral. Nutrition of Higher Plants, 3rd ed.; Academic Press: San Diego, CA, USA, $2012 ;$ pp. 1-651.

7. Gruszecka-Kosowska, A. Potentially harmful element concentrations in the vegetables cultivated on arable soils, with human health-risk implications. Int. J. Environ. Res. Public Health 2019, 16, 4053. [CrossRef]

8. Tchounwou, P.B.; Yedjou, C.G.; Patlolla, A.K.; Sutton, D.J. Heavy metal toxicity and the environment. Mol. Clin. Exp. Toxicol. 2012, 101, 133-164. [CrossRef]

9. Alloway, B.J. Heavy metals and metalloids as micronutrients for plants and animals. In Heavy Metals in Soils: Trace Metals and Metalloids in Soils and Their Bioavailability; Alloway, B.J., Ed.; Springer: Dordrecht, The Netherlands, 2013; pp. $195-209$.

10. Okereafor, U.; Makhatha, M.; Mekuto, L.; Uche-Okereafor, N.; Sebola, T.; Mavumengwana, V. Toxic metal implications on agricultural soils, plants, animals, aquatic life and human health. Int. J. Environ. Res. Public Health 2020, 17, 2204. [CrossRef]

11. Ali, H.; Khan, E. Bioaccumulation of non-essential hazardous heavy metals and metalloids in freshwater fish. Risk to human health. Environ. Chem. Lett. 2018, 16, 903-917. [CrossRef]

12. Rai, P.K.; Lee, S.S.; Zhang, M.; Tsang, Y.F.; Kim, K.-H. Heavy metals in food crops: Health risks, fate, mechanisms, and management. Environ. Int. 2019, 125, 365-385. [CrossRef] [PubMed]

13. Gall, J.E.; Boyd, R.S.; Rajakaruna, N. Transfer of heavy metals through terrestrial food webs: A review. Environ. Monit. Assess. 2015, 187, 1-21. [CrossRef]

14. Pu, W.; Sun, J.; Zhang, F.; Wen, X.; Liu, W.; Huang, C. Effects of copper mining on heavy metal contamination in a rice agrosystem in the Xiaojiang River Basin, southwest China. Acta Geochim. 2019, 38, 753-773. [CrossRef]

15. Chen, X.-X.; Liu, Y.-M.; Zhao, Q.-Y.; Cao, W.-Q.; Chen, X.-P.; Zou, C.-Q. Health risk assessment associated with heavy metal accumulation in wheat after long-term phosphorus fertilizer application. Environ. Pollut. 2020, 262, 114348. [CrossRef]

16. Kpomblekou-A, K.; Tabatabai, M.A. Metal contents of phosphate rocks. Commun. Soil Sci. Plant. Anal. 1994, 25, $2871-2882$. [CrossRef]

17. Sabiha-Javied, M.T.; Chaudhry, M.M.; Tufail, M.; Irfan, N. Heavy metal pollution from phosphate rock used for the production of fertilizer in Pakistan. Microchem. J. 2009, 91, 94-99. [CrossRef]

18. Faridullah, F.; Umar, M.; Alam, A.; Sabir, M.A.; Khan, D. Assessment of heavy metals concentration in phosphate rock deposits, Hazara basin, Lesser Himalaya Pakistan. Geosci. J. 2017, 21, 743-752. [CrossRef]

19. Mar, S.S.; Okazaki, M. Investigation of Cd contents in several phosphate rocks used for the production of fertilizer. Microchem. J. 2012, 104, 17-21. [CrossRef]

20. Siddique, A.; Hassan, A.; Khan, S.R.; Inayat, A.; Nazir, A.; Iqbal, M. Appraisal of heavy metals and nutrients from phosphate rocks, Khyber Pakhtunkhwa, Pakistan. Chem. Int. 2018, 4, 1-6.

21. Wang, X.; Xiong, J.; He, Z. Activated dolomite phosphate rock fertilizers to reduce leaching of phosphorus and trace metals as compared to superphosphate. J. Environ. Manag. 2020, 255, 109872. [CrossRef] [PubMed]

22. Nziguheba, G.; Smolders, E. Inputs of trace elements in agricultural soils via phosphate fertilizers in European countries. Sci. Total Environ. 2008, 390, 53-57. [CrossRef] [PubMed]

23. da Silva, F.B.V.; do Nascimento, C.W.A.; Araújo, P.R.M. Environmental risk of trace elements in P-containing fertilizers marketed in Brazil. J. Soil Sci. Plant Nutr. 2017, 17, 635-647. [CrossRef]

24. EU. Regulation (EU) 2019/1009 of the European Parliament and of the Council of 5 June 2019 laying down rules on the making available on the market of EU fertilising products and amending Regulations (EC) No 1069/2009 and (EC) No 1107/2009 and repealing Regulation (EC) No 2003/2003 (Text with EEA relevance). Off. J. Eur. Union 2019, L170, 1-114.

25. Mortvedt, J.J. Heavy metal contaminants in inorganic and organic fertilizers. Fert. Environ. 1995, 43, 55-61. [CrossRef]

26. Ulrich, A.E. Cadmium governance in Europe's phosphate fertilizers: Not so fast? Sci. Total Environ. 2019, 650, 541-545. [CrossRef] [PubMed]

27. Barquet, K.; Järnberg, L.; Rosemarin, A.; Macura, B. Identifying barriers and opportunities for a circular phosphorus economy in the Baltic Sea region. Water Res. 2020, 171, 115433. [CrossRef] 
28. van Dijk, K.C.; Lesschen, J.P.; Oenema, O. Phosphorus flows and balances of the European Union Member States. Sci. Total Environ. 2016, 542, 1078-1093. [CrossRef]

29. Schröder, J.J.; Smit, A.L.; Cordell, D.; Rosemarin, A. Improved phosphorus use efficiency in agriculture: A key requirement for its sustainable use. Chemosphere 2011, 84, 822-831. [CrossRef] [PubMed]

30. Huang, J.; Xu, C.-c.; Ridoutt, B.G.; Wang, X.-c.; Ren, P.-a. Nitrogen and phosphorus losses and eutrophication potential associated with fertilizer application to cropland in China. J. Clean. Prod. 2017, 159, 171-179. [CrossRef]

31. Zhu, J.; Li, M.; Whelan, M. Phosphorus activators contribute to legacy phosphorus availability in agricultural soils: A review. Sci. Total Environ. 2018, 612, 522-537. [CrossRef] [PubMed]

32. El Wali, M.; Golroudbary, S.R.; Kraslawski, A. Circular economy for phosphorus supply chain and its impact on social sustainable development goals. Sci. Total Environ. 2021, 777, 146060. [CrossRef] [PubMed]

33. Chojnacka, K.; Moustakas, K.; Witek-Krowiak, A. Bio-based fertilizers: A practical approach towards circular economy. Bioresour. Technol. 2020, 295, 122223. [CrossRef] [PubMed]

34. Saeid, A.; Wyciszkiewicz, M.; Jastrzebska, M.; Chojnacka, K.; Gorecki, H. A concept of production of new generation of phosphorus-containing biofertilizers. BioFertP project. Przem. Chem. 2015, 94, 361-365. [CrossRef]

35. Wyciszkiewicz, M.; Sojka, M.; Saeid, A. Production of phosphorus biofertilizer based on the renewable materials in large laboratory scale. Open Chem. 2019, 17, 893-901. [CrossRef]

36. Herzel, H.; Stemann, J.; Simon, S.; Adam, C. Comparison of thermochemical treatment of sewage sludge ash with sodium sulphate in laboratory-scale and pilot-scale experiments. Int. J. Environ. Sci. Technol. 2021, 1-10. [CrossRef]

37. Ottosen, L.M.; Kirkelund, G.M.; Jensen, P.E. Extracting phosphorous from incinerated sewage sludge ash rich in iron or aluminum. Chemosphere 2013, 91, 963-969. [CrossRef]

38. Nanzer, S.; Oberson, A.; Huthwelker, T.; Eggenberger, U.; Frossard, E. The molecular environment of phosphorus in sewage sludge ash: Implications for bioavailability. J. Environ. Qual. 2014, 43, 1050-1060. [CrossRef]

39. Lekfeldt, J.D.S.; Rex, M.; Mercl, F.; Kulhánek, M.; Tlustoš, P.; Magid, J.; de Neergaard, A. Effect of bioeffectors and recycled P-fertiliser products on the growth of spring wheat. Chem. Biol. Technol. Agric. 2016, 3, 22. [CrossRef]

40. Römer, W.; Steingrobe, B. Fertilizer effect of phosphorus recycling products. Sustainability 2018, 10, 1166. [CrossRef]

41. Weigand, H.; Bertau, M.; Hübner, W.; Bohndick, F.; Bruckert, A. RecoPhos: Full-scale fertilizer production from sewage sludge ash. Waste Manag. 2013, 33, 540-544. [CrossRef]

42. Krüger, O.; Adam, C. Recovery potential of German sewage sludge ash. Waste Manag. 2015, 45, 400-406. [CrossRef]

43. Smol, M.; Adam, C.; Kugler, S.A. Thermochemical treatment of sewage sludge ash (SSA)-potential and perspective in Poland. Energies 2020, 13, 5461. [CrossRef]

44. Smol, M. Inventory of wastes generated in Polish sewage sludge incineration plants and their possible circular management directions. Resources 2020, 9, 91. [CrossRef]

45. Staroń, A.; Kowalski, Z.; Banach, M.; Wzorek, Z. Sposoby termicznej utylizacji odpadów z przemysłu mięsnego. Czas. Techn. Chemia 2010, 107, 323-332.

46. Nelson, N.; Mikkelsen, R. Meeting the phosphorus requirement on organic farms. Better Crops 2008, 92, 12-14.

47. Wyciszkiewicz, M.; Saeid, A.; Malinowski, P.; Chojnacka, K. Valorization of phosphorus secondary raw materials by Acidithiobacillus ferrooxidans. Molecules 2017, 22, 473. [CrossRef]

48. Wisniak, J. Phosphorus-from discovery to commodity. Indian J. Chem. Technol. 2005, 12, 108-122.

49. EU. Commission Regulation (EU) No 142/2011 of 25 February 2011 implementing Regulation (EC) No 1069/2009 of the European Parliament and of the Council laying down health rules as regards animal by-products and derived products not intended for human consumption and implementing Council Directive 97/78/EC as regards certain samples and items exempt from veterinary checks at the border under that Directive Text with EEA relevance. Off. J. Eur. Union 2011, L54, 1-254.

50. Załuszniewska, A.; Nogalska, A. The effect of meat and bone meal (MBM) on the seed yield and quality of winter oilseed rape. Agronomy 2020, 10, 1952. [CrossRef]

51. Kivelä, J.; Chen, L.; Muurinen, S.; Kivijärvi, P.; Hintikainen, V.; Helenius, J. Effects of meat bone meal as fertilizer on yield and quality of sugar beet and carrot. Agric. Food Sci. 2015, 24, 68-83. [CrossRef]

52. Delin, S.; Engström, L.; Lundkvist, A. Optimal Placement of Meat Bone Meal Pellets to Spring Oats. Front. Sustain. Food Syst. 2018, 2, 27. [CrossRef]

53. Jatana, B.S.; Kitchens, C.; Ray, C.; Tharayil, N. Regulating the nutrient release rates from proteinaceous agricultural byproducts using organic amendments and its effect on soil chemical and microbiological properties. Biol. Fertil. Soils 2020, 56, 747-758. [CrossRef]

54. Jeng, A.S.; Haraldsen, T.K.; Grønlund, A.; Pedersen, P.A. Meat and bone meal as nitrogen and phosphorus fertilizer to cereals and rye grass. Nutr. Cycl. Agroecosystems 2006, 76, 183-191. [CrossRef]

55. Balawejder, M.; Matłok, N.; Gorzelany, J.; Pieniążek, M.; Antos, P.; Witek, G.; Szostek, M. Foliar fertilizer based on calcined bones, boron and molybdenum—a study on the development and potential effects on maize grain production. Sustainability 2019, 11, 5287. [CrossRef]

56. Balawejder, M.; Szostek, M.; Gorzelany, J.; Antos, P.; Witek, G.; Matłok, N. A study on the potential fertilization effects of microgranule fertilizer based on the protein and calcined bones in maize cultivation. Sustainability 2020, 12, 1343. [CrossRef] 
57. Piccolla, C.D.; Hesterberg, D.; Muraoka, T.; Novotny, E.H. Optimizing pyrolysis conditions for recycling pig bones into phosphate fertilizer. Waste Manag. 2021, 131, 249-257. [CrossRef]

58. Saeid, A.; Labuda, M.; Chojnacka, K.; Górecki, H. Use of microorganism in production of phosphorus fertilizers. Przem. Chem. 2012, 91, 956-958.

59. Jastrzębska, M.; Kostrzewska, M.K.; Saeid, A. Can phosphorus from recycled fertilisers replace conventional sources? An agronomic evaluation in field-scale experiments on temperate Luvisols. Appl. Sci. 2019, 9, 2086. [CrossRef]

60. Jastrzębska, M.; Saeid, A.; Kostrzewska, M.K.; Baśladyńska, S. New phosphorus biofertilizers from renewable raw materials in the aspect of cadmium and lead contents in soil and plants. Open Chem. 2018, 16, 35-49. [CrossRef]

61. Rolewicz, M.; Rusek, P.; Mikos-Szymańska, M.; Cichy, B.; Dawidowicz, M. Obtaining of suspension fertilizers from incinerated sewage sludge ashes (ISSA) by a method of solubilization of phosphorus compounds by Bacillus megaterium bacteria. Waste Biomass Valorization 2016, 7, 871-877. [CrossRef]

62. Rolewicz, M.; Rusek, P.; Borowik, K. Obtaining of granular fertilizers based on ashes from combustion of waste residues and ground bones using phosphorous solubilization by bacteria Bacillus megaterium. J. Environ. Manag. 2018, 216, 128-132. [CrossRef]

63. Polish Standard. General Requirements for the Competence of Testing and Calibration Laboratories; PN-EN ISO/IEC 17025:2005; Committee for Standardization: Warsaw, Poland, 2005.

64. MARD-PL. Regulation of the Minister of Agriculture and Rural Development of 18 June 2008 regarding the implementation of certain provisions of the Act on fertilizers and fertilization. J. Laws 2008, 119, 765.

65. Woś, A. Klimat Polski; Wydawnictwo Naukowe PWN: Warsaw, Poland, 1999.

66. Grabowski, J. Charakterystyka stosunków termicznych występujących w Rolniczym Zakładzie Doświadczalnym w Bałcynach w latach 1972-1990. Acta Acad. Agricult. Techn. Olst. Agricultura 1995, 60, 3-13.

67. Food and Agriculture Organization of the United Nations. World reference base for soil resources 2014. In International Soil Classification System for Naming Soils and Creating Legends for Soil Maps; Food and Agriculture Organization of the United Nations: Rome, Italy, 2014.

68. Polish Standard. Soil Quality and Determination of pH; PN-ISO 10390:1997; Polish Committee for Standardization: Warsaw, Poland, 1997.

69. Czarnowska, K. Total content of heavy metals in parent rocks as reference background levels of soils. Soil Sci. Annu. 1996, $47,43-50$.

70. Kucharczak-Moryl, E.; Moryl, A.; Żmuda, R. Influence of the environment on the content of arsenic in cultivated soils in Zgorzelec-Bogatynia region. Ecol. Eng. Environ. Technol. 2014, 37, 107-116.

71. Kabata-Pendias, A.; Pendias, H. Biogeochemistry of Trace Elements; Polish Scientific Publishing Company: Warsaw, Poland, 1999; pp. $1-400$.

72. ME-PL. Ordinance by the Minister of the Environment of 1 September 2016 on assessment procedures for the land surface pollution. J. Laws 2016, 2016, 1395.

73. IUNG. The Monitoring of the Chemistry of the Polish Arable Soils; Institute of Soil Science and Plant Cultivation: Puławy, Poland, 2017.

74. MH-PL. Ordinance by the Minister of Health of 13 January 2003 on maximum concentrations of chemical and biological impurities which may be present in food, food ingredients, permitted supplementary substances and substances helpful in food processing. J. Laws 2003, 37, 326.

75. MARD-PL. Ordinance by the Minister of Agriculture and Rural Development of 25 August 2014 amending the ordinance on the content of undesirable substances in animal feed. J. Laws 2014, 37, 1213.

76. MARD-PL. Ordinance by the Minister of Agriculture and Rural Development (Poland) of 29 June 2019 amending the ordinance on the content of undesirable substances in animal feed. J. Laws 2018, 2018, 1213.

77. FAO-WHO. Codex Alimentarius. General Standard for Contaminants and Toxins in Food and Feed. CXS 193-1995; Food and Agricultural Organization ff the United Nation, World Health Organization: Rome, Italy, 2019.

78. EU. Commission Regulation (EU) 2015/1006 of 25 June 2015 amending Regulation (EC) No 1881/2006 as regards maximum levels of inorganic arsenic in foodstuffs (Text with EEA relevance). Off. J. Eur. Union 2015, L161, 14-16.

79. USDA-FAS. China Releases the Standard for Maximum Levels of Contaminants in Foods; Office of Agricultural Affairs: Beijing, China, 2018; pp. 1-17.

80. Kabata-Pendias, A.; Motowicka-Terelak, T.; Piotrowska, M.; Terelak, H.; Witek, T. Ocena Stopnia Zanieczyszczenia Gleb i Roślin Metalami Ciężkimi i Siarka. Ramowe Wytyczne dla Rolnictwa; IUNG: Puławy, Poland, 1993; pp. 1-20.

81. Pres, J.; Kinal, S. Aktualne spojrzenie na sprawe zaopatrzenia zwierzat w mikroelementy. Zesz. Probl. Post. Nauk Rol. 1996, 434, 1042-1061.

82. Wiśniowska-Kielian, B. Effect of soil moisture content on the absorption of heavy metals by plants. Zesz. Probl. Post. Nauk Rol. 2000, 472, 679-688.

83. Gancarczyk-Gola, M.; Palowski, B. Heavy metals and acidity of surface soil horizons in surroundings of industrial centers and in non-contaminated regions. Rocz. Glebozn. 2005, 56, 59-66.

84. Meteorological Data. Ten Days and Monthly Precipitation (Sum) and Air Temperature (Average) in Batcyny in 2014-2016; 2014-2016 (Data in Exel Worksheet form Made Available Upon Request); Meteorological Station in Bałcyny of the University of Warmia and Mazury in Olsztyn: Olsztyn, Poland, 2021. 
85. Górecka, H.; Chojnacka, K.; Górecki, H. The application of ICP-MS and ICP-OES in determination of micronutrients in wood ashes used as soil conditioners. Talanta 2006, 70, 950-956. [CrossRef]

86. Statsoft Inc. Statistica (Data Analysis Software System), Version 13.3; Statsoft Inc.: Tulsa, OK, USA, 2016.

87. EC. Final Implementation Report for Directive 86/278/EEC on Sewage Sludge: 2013-2015; Eunomia Research \& Consulting Ltd.: Bristol, UK, 2018.

88. Kantek, K.; Korzeniowska, J. Potrzeby nawożenia zbóż mikroelementami w Województwie Dolnośląskim. Stud. Rap. IUNG-PIB 2013, 34, 145-157.

89. Stępień, A.; Wojtkowiak, K. Effect of foliar application of $\mathrm{Cu}, \mathrm{Zn}$, and $\mathrm{Mn}$ on yield and quality indicators of winter wheat grain Chil. J. Agric. Res. 2016, 76, 220-227. [CrossRef]

90. Tani, F.H.; Barrington, S. Zinc and copper uptake by plants under two transpiration rates. Part I. Wheat (Triticum aestivum L.). Environ. Pollut. 2005, 138, 538-547. [CrossRef] [PubMed]

91. Sharma, A.; Kapoor, D.; Wang, J.; Shahzad, B.; Kumar, V.; Bali, A.S.; Jasrotia, S.; Zheng, B.; Yuan, H.; Yan, D. Chromium bioaccumulation and its impacts on plants: An overview. Plants 2020, 9, 100. [CrossRef]

92. Singh, H.P.; Mahajan, P.; Kaur, S.; Batish, D.R.; Kohli, R.K. Chromium toxicity and tolerance in plants. Environ. Chem. Lett. 2013, 11, 229-254. [CrossRef]

93. Wei, B.; Yu, J.; Cao, Z.; Meng, M.; Yang, L.; Chen, Q. The availability and accumulation of heavy metals in greenhouse soils associated with intensive fertilizer application. Int. J. Environ. Res. Public Health 2020, 17, 5359. [CrossRef]

94. Martinez, J.; Peu, P. Nutrient fluxes from a soil treatment process for pig slurry. Soil Use Manag. 2000, 16, 100-107. [CrossRef]

95. Xu, Y.; Yu, W.; Ma, Q.; Zhou, H. Accumulation of copper and zinc in soil and plant within ten-year application of different pig manure rates. Plant Soil Environ. 2013, 59, 492-499. [CrossRef]

96. Jiao, W.; Chen, W.; Chang, A.C.; Page, A.L. Environmental risks of trace elements associated with long-term phosphate fertilizers applications: A review. Environ. Pollut. 2012, 168, 44-53. [CrossRef]

97. Chen, W.; Chang, A.C.; Wu, L. Assessing long-term environmental risks of trace elements in phosphate fertilizers. Ecotoxicol. Environ. Saf. 2007, 67, 48-58. [CrossRef]

98. Atafar, Z.; Mesdaghinia, A.; Nouri, J.; Homaee, M.; Yunesian, M.; Ahmadimoghaddam, M.; Mahvi, A.H. Effect of fertilizer application on soil heavy metal concentration. Environ. Monit. Assess. 2010, 160, 83-89. [CrossRef]

99. Belhaj, D.; Elloumi, N.; Jerbi, B.; Zouari, M.; Abdallah, F.B.; Ayadi, H.; Kallel, M. Effects of sewage sludge fertilizer on heavy metal accumulation and consequent responses of sunflower (Helianthus annuus). Environ. Sci. Pollut. Res. 2016, 23, 20168-20177. [CrossRef] [PubMed]

100. Uprety, D.; Hejcman, M.; Száková, J.; Kunzová, E.; Tlustoš, P. Concentration of trace elements in arable soil after long-term application of organic and inorganic fertilizers. Nutr. Cycl. Agroecosystems 2009, 85, 241-252. [CrossRef]

101. Thielecke, F.; Nugent, A.P. Contaminants in grain-a major risk for whole grain safety? Nutrients 2018, 10, 1213. [CrossRef]

102. Hashemi, M. Heavy metals concentrations in dairy cow feedstuffs from the south of Iran. Food Addit. Contam. Part B 2020, 13, 10-15. [CrossRef] [PubMed]

103. Kulczycki, G.; Sacała, E. Sulfur application alleviates chromium stress in maize and wheat. Open Chem. 2020, 18, 1093-1104. [CrossRef]

104. Korzeniowska, J.; Kantek, K. Biofortifcation of wheat grain with copper through soil fertilization. Environ. Prot. Nat. Resour. 2014, 25, 23-27. [CrossRef]

105. Wang, M.; Kong, F.; Liu, R.; Fan, Q.; Zhang, X. Zinc in wheat grain, processing, and food. Front. Nutr. 2020, 7, 124. [CrossRef]

106. Liu, W.-X.; Liu, J.-W.; Wu, M.-Z.; Li, Y.; Zhao, Y.; Li, S.-R. Accumulation and translocation of toxic heavy metals in winter wheat (Triticum aestivum L.) growing in agricultural soil of Zhengzhou, China. Bull. Environ. Contam. Toxicol. 2009, 82, 343-347. [CrossRef]

107. Al-Othman, Z.A.; Ali, R.; Al-Othman, A.M.; Ali, J.; Habila, M.A. Assessment of toxic metals in wheat crops grown on selected soils, irrigated by different water sources. Arab. J. Chem. 2016, 9, S1555-S1562. [CrossRef]

108. Kundu, R.; Bhattacharyya, K.; Majumder, A.; Pal, S. Response of wheat cultivars to arsenic contamination in polluted soils of West Bengal, India. Cereal Res. Commun. 2013, 41, 66-77. [CrossRef]

109. Kumar, R.; Mehrotra, N.K.; Nautiyal, B.D.; Kumar, P.; Singh, P.K. Effect of copper on growth, yield and concentration of Fe, Mn, $\mathrm{Zn}$ and $\mathrm{Cu}$ in wheat plants (Triticum aestivum L.). J. Environ. Biol. 2009, 30, 485-488.

110. Korzeniowska, J.; Stanislawska-Glubiak, E. Copper concentration in the top plant tissue as an indicator of Cu toxicity. Electron. J. Pol. Agric. Univ. 2003, 6. Available online: http://www.ejpau.media.pl/volume6/issue1/environment/art-02.html (accessed on 12 July 2021).

111. Garnett, T.P.; Graham, R.D. Distribution and remobilization of iron and copper in wheat. Ann. Bot. 2005, 95, 817-826. [CrossRef]

112. Hill, J.; Robson, A.D.; Loneragan, J.F. The effects of copper and nitrogen supply on the retranslocation of copper in four cultivars of wheat. Aust. J. Agric. Res. 1978, 29, 925-939. [CrossRef]

113. Jastrzębska, M.; Kostrzewska, M.K.; Treder, K.; Makowski, P.; Jastrzębski, W.P. Functional properties of granulated ash and bone-based phosphorus biofertilizers in the field assessment. Part 2. Impact on selected morphological and physiological atributes of winter wheat. Przem. Chem. 2016, 95, 1586-1590. [CrossRef]

114. Liu, D.-Y.; Liu, Y.-M.; Zhang, W.; Chen, X.-P.; Zou, C.-Q. Zinc uptake, translocation, and remobilization in winter wheat as affected by soil application of Zn fertilizer. Front. Plant Sci. 2019, 10, 426. [CrossRef] [PubMed] 
115. Xue, Y.-F.; Zhang, W.; Liu, D.-Y.; Yue, S.-C.; Cui, Z.-L.; Chen, X.-P.; Zou, C.-Q. Effects of nitrogen management on root morphology and zinc translocation from root to shoot of winter wheat in the field. Field Crop. Res. 2014, 161, 38-45. [CrossRef]

116. Pascoalino, J.A.L.; Thompson, J.A.; Wright, G.; Franco, F.A.; Scheeren, P.L.; Pauletti, V.; Moraes, M.F.; White, P.J. Grain zinc concentrations differ among brazilian wheat genotypes and respond to zinc and nitrogen supply. PLoS ONE 2018, 13, e0199464. [CrossRef]

117. Gondek, K. Wpływ nawożenia mineralnego, obornikiem i osadem garbarskim na zawartość wybranych metali ciężkich w roślinach i glebie. Acta Agrophys. 2004, 3, 465-478.

118. Iżewska, A.; Wołoszyk, C. Contents of heavy metals in plants and soil fertilization of ash from sewage sludge combustion. Ecol. Chem. Eng. A 2013, 20, 1019-1027. [CrossRef]

119. ME-PL. Regulation of the Minister of the Environment of January 20, 2015 regarding the R10 recovery process. J. Laws 2015, 2015, 132.

120. ME-PL. Regulation of the Minister of the Environment, Republic of Poland, Catalogue of waste. J. Laws 2020, $2020,10$.

121. Kirchmann, H.; Börjesson, G.; Kätterer, T.; Cohen, Y. From agricultural use of sewage sludge to nutrient extraction: A soil science outlook. Ambio 2017, 46, 143-154. [CrossRef] [PubMed]

122. Wierzbowska, J.; Sienkiewicz, S.; Sternik, P.; Busse, M.K. Using ash from incineration of municipal sewage sludge to fertilize Virginia fanpetals. Ecol. Chem. Eng. A 2015, 22, 497-507. [CrossRef]

123. Zalewska, M.; Steppień, A.; Wierzbowska, J. Agronomic evaluation of dried sewage sludge and sewage sludge ash as sources of nutrients for maize. J. Elem. 2020, 25, 771-785. [CrossRef]

124. Arroyo, M.d.M.D.; Hornedo, R.M.D.I.; Peralta, F.A.; Almestre, C.R.; Sánchez, J.V.M. Heavy metals concentration in soil, plant, earthworm and leachate from poultry manure applied to agricultural land. Rev. Int. Contam. Ambient. 2014, 30, 43-50.

125. Wang, F.; Wang, Z.; Kou, C.; Ma, Z.; Zhao, D. Responses of wheat yield, macro- and micro-nutrients, and heavy metals in soil and wheat following the application of manure compost on the North China Plain. PLoS ONE 2016, 11, e0146453. [CrossRef]

126. Staugaitis, G.; Narutyte, I.; Arbačauskas, J.; Vaišvila, Z.; Rainys, K.; Mažeika, R.; Masevičienè, A.; Žičkienè, L.; Šumskis, D. The influence of composts on yield and chemical elements of winter wheat and spring barley. Zemdirb. Agric. 2016, 103, 355-362. [CrossRef]

127. Godlewska, A. Changes in the contents of selected heavy metals in test plants fertilised with sewage sludge and hard coal ash. J. Ecol. Eng. 2017, 18, 97-102. [CrossRef]

128. Chetyrbotskiy, V.A.; Chetyrbotskiy, A.N.; Levin, B.V. Mathematical modeling of the dynamics of plant mineral nutrition in the fertilizer-soil-plant system. Biophysics 2020, 65, 1036-1045. [CrossRef]

129. Harre, N.T.; Young, B.G. Early-season nutrient competition between weeds and soybean. J. Plant. Nutr. 2020, 43, 1887-1906. [CrossRef]

130. Jarrell, W.M.; Beverly, R.B. The dilution effect in plant nutrition studies. In Advances in Agronomy; Brady, N.C., Ed.; Academic Press: London, UK, 1981; Volume 34, pp. 197-224.

131. Wołejko, E.; Łozowicka, B.; Kaczyński, P.; Konecki, R.; Grobela, M. The influence of chemical protection on the content of heavy metals in wheat (Triticum aestivum L.) growing on the soil enriched with granular sludge. Environ. Monit. Assess. 2017, 189, 1-12. [CrossRef] [PubMed]

132. Babar, M.A.; Khan, A.; Azam, S.; Ikramullah; Arif, M.; Hussain, S. Weeds in wheat crop: Weed whole plants nutrient concentration and uptake under fertilizer application and irrigation frequencies. Pure Appl. Biol. 2019, 8, 1724-1735. [CrossRef]

133. Ashrafi, A.; Zahedi, M.; Fahmi, K.; Nadi, R. Neighbour effects of purslane (Portulaca oleracea L.) on Cd bioaccumulation by soybean in saline soil. Plant Soil Environ. 2014, 60, 439-445. [CrossRef]

134. Gove, B.; Hutchinson, J.J.; Young, S.D.; Craigon, J.; McGrath, S.P. Uptake of metals by plants sharing a rhizosphere with the hyperaccumulator Thlaspi caerulescens. Int. J. Phytoremediation 2002, 4, 267-281. [CrossRef]

135. Stupnicka-Rodzynkiewicz, E.; Labza, T.; Hochol, T. Content of some mineral components in weeds with respect to environmental conditions. Acta Agrar. Silvestria Ser. Agrar. 1996, 34, 125-130.

136. Łabza, T.; Stupnicka-Rodzynkiewicz, E.; Hochół, T. Zawartość niklu w wybranych chwastach segetalnych. Zesz. Probl. Post. Nauk Rol. 1997, 448, 183-188.

137. Roy, S.; Mondal, S. Brassicaceae plants response and tolerance to metal/metalloid toxicity. In The Plant Family Brassicaceae; Springer: Singapore, 2020; pp. 363-377.

138. Sharma, P.; Tripathi, S.; Chandra, R. Phytoremediation potential of heavy metal accumulator plants for waste management in the pulp and paper industry. Heliyon 2020, 6, e04559. [CrossRef]

139. Zubkova, V.; Belozubova, N.; Arslanbekova, F.; Gaponenko, A.; Gorbunova, V. Species Peculiarities of Weeds in Terms of Heavy Metal Accumulation. KnE Life Sci. 2021, 774-779. [CrossRef]

140. Słomka, A.; Sutkowska, A.; Szczepaniak, M.; Malec, P.; Mitka, J.; Kuta, E. Increased genetic diversity of Viola tricolor L. (Violaceae) in metal-polluted environments. Chemosphere 2011, 83, 435-442. [CrossRef]

141. Łabza, T.; Stupnicka-Rodzynkiewicz, E.; Hochol, T. Zawartość cynku i miedzi w wybranych chwastach segetalnych. Zesz. Probl. Post. Nauk Rol. 1996, 434, 307-312.

142. Głowacka, A. Content and uptake of microelements (Cu, Zn, Mn, Fe) by maize (Zea mays L.) and accompanying weeds. Acta Agrobot. 2012, 65, 179-188. [CrossRef] 
143. Kumar, N.; Bauddh, K.; Kumar, S.; Dwivedi, N.; Singh, D.P.; Barman, S.C. Accumulation of metals in weed species grown on the soil contaminated with industrial waste and their phytoremediation potential. Ecol. Eng. 2013, 61, 491-495. [CrossRef]

144. Zhao, S.; Duo, L. Bioaccumulation of cadium, copper, zinc, and nickel by weed species from municipal solid waste compost. Pol. J. Environ. Stud. 2015, 24, 413-417. [CrossRef]

145. Wang, J.; Xiong, Y.; Zhang, J.; Lu, X.; Wei, G. Naturally selected dominant weeds as heavy metal accumulators and excluders assisted by rhizosphere bacteria in a mining area. Chemosphere 2020, 243, 125365. [CrossRef] [PubMed]

146. Galal, T.M.; Shehata, H.S. Impact of nutrients and heavy metals capture by weeds on the growth and production of rice (Oryza sativa L.) irrigated with different water sources. Ecol. Indic. 2015, 54, 108-115. [CrossRef]

147. Kaur, S.; Kaur, R.; Chauhan, B.S. Understanding crop-weed-fertilizer-water interactions and their implications for weed management in agricultural systems. Crop Prot. 2018, 103, 65-72. [CrossRef]

148. Palansooriya, K.N.; Shaheen, S.M.; Chen, S.S.; Tsang, D.C.W.; Hashimoto, Y.; Hou, D.; Bolan, N.S.; Rinklebe, J.; Ok, Y.S. Soil amendments for immobilization of potentially toxic elements in contaminated soils: A critical review. Environ. Int. 2020, 134, 105046. [CrossRef] [PubMed]

149. Fu, B.; Chen, L.; Huang, H.; Qu, P.; Wei, Z. Impacts of crop residues on soil health: A review. Environ. Pollut. Bioavailab. 2021, 33, 164-173. [CrossRef]

150. Barman, S.C.; Sahu, R.K.; Bhargava, S.K.; Chaterjee, C. Distribution of heavy metals in wheat, mustard, and weed grown in field irrigated with industrial effluents. Bull. Environ. Contam. Toxicol. 2000, 64, 489-496. [CrossRef] [PubMed]

151. Zhang, W.D.; Liu, D.S.; Tian, J.C.; He, F.L. Toxicity and accumulation of arsenic in wheat (Triticum aestivum L.) varieties of China. Phyton 2009, 78, 147-154.

152. Asdeo, A. Toxic metal contamination of staple crops (wheat and millet) in periurban area of Western Rajasthan. Int. Ref. J. Eng. Sci. 2014, 3, 8-18.

153. Impa, S.M.; Morete, M.J.; Ismail, A.M.; Schulin, R.; Johnson-Beebout, S.E. Zn uptake, translocation and grain Zn loading in rice (Oryza sativa L.) genotypes selected for Zn deficiency tolerance and high grain Zn. J. Exp. Bot. 2013, 64, 2739-2751. [CrossRef] [PubMed]

154. Blanco-Canqui, H.; Ruis, S.J.; Proctor, C.A.; Creech, C.F.; Drewnoski, M.E.; Redfearn, D.D. Harvesting cover crops for biofuel and livestock production: Another ecosystem service? Agron. J. 2020, 112, 2373-2400. [CrossRef] 